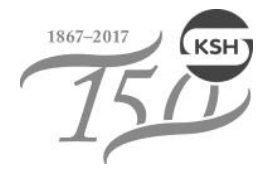

\title{
A magyar árstatisztika 150 éve
}

Süveges Évo,

a Központi Statisztikai Hivatal ny. főosztályvezetője

E-mail: suvegese@gmail.com
Az elmúlt 150 évben jelentős fejlődési utat járt be a hivatalos árstatisztika. Kezdetben a nagyobb piacokon, illetve a tőzsdén feljegyzett, főleg mezőgazdasági termékek árainak, valamint a bányák termelöiáradatainak átvételére, feldolgozására és publikálására vállalkozott a KSH (Központi Statisztikai Hivatal). Később a termelői (mezőgazdasági, ipari, építőipari, üzleti szolgáltatási) és külkereskedelmi vállalkozásoktól a hivatal által kidolgozott kérdőíveken begyüjtött, míg a fogyasztóiár-statisztikában alapvetően összeírók által a piacokon, üzletekben és szolgáltatóhelyeken felírt áradatokra épült a hivatalos árstatisztika. A hazai felhasználói igények mellett az EU-hoz (Európai Unió) való csatlakozást követően a közösségi elöírások teljesítése vált meghatározó feladattá. A fejlesztések középpontjában jelenleg az ármegfigyelésekből még hiányzó üzleti szolgáltatásiár-indexek, majd egy egységes szolgáltatásiár-index kidolgozása áll.

TÁRGYSZÓ:

Árstatisztika.

Történeti statisztika.

DOI: 10.20311/stat2018.07.hu0709 
A KSH fennállásának 150. évfordulója alkalmat teremt a hivatalos árstatisztika történetének áttekintésére is. A következőkben alapvetően a hivatal által számított és publikált árakra és árindexekre koncentrálunk, csak röviden térünk ki a hivatalos statisztikai szolgálaton kívüli fontosabb adatokra. Elsősorban a statisztikai évkönyvekben megjelent árstatisztikai adatokat mutatjuk be. Emellett sorra vesszük a Statisztikai Szemlében (illetve a részben elödjének tekinthető Statisztikai Közleményekben) megjelent fontosabb árstatisztikai adat-összeállításokat, -elemzéseket, valamint a szakmai évkönyveket és módszertani kiadványokat is. Terjedelmi okokból csak érintőlegesen foglalkozunk árstatisztikai elméleti, módszertani kérdésekkel.

A hivatalos árstatisztika 150 éves története a különböző forrásokból származó egyedi áradatok összegyüjtésétől és közzétételétől a fogyasztás, a külkereskedelem, a termelés és a szolgáltatás összevont csoportjainak ármozgását koncentráltan mutató árindexek előállításáig ível. Időközben jelentős lépések történtek a szakterületek árainak gyűjtési és feldolgozási módszertanában, közlési formáiban is.

Az árak mozgásának megismerése önmagában is fontos információval szolgál a gazdasági vezetés, a gazdasági élet szereplői, valamint a lakosság számára. Emellett az ún. deflátor árindexek teszik lehetővé az értékindexekből az ármozgásoktól megtisztított volumenindexek előállítását. A nemzetiszámla-számítások a termelés és felhasználás teljes területét lefedő árindexek előállítását igénylik. E feladat teljesítésében, bár jelentős elörelépések történtek, még további tennivalók állnak a hazai árstatisztika elött.

Az árstatisztika fejlődése - más szakstatisztikákhoz hasonlóan - nem volt töretlen. A bővülő adatkörök publikálását és a folyamatos módszertani fejlesztést megvalósító béke éveit az első és a második világháború megakasztotta, majd a szocialista tervgazdálkodásra való áttérés szinte az alapoktól kezdve új irányokat szabott a fejlesztéseknek. Az 1950-es éveket követően az 1968-as új gazdasági mechanizmus, az 1989-es rendszerváltás, majd az EU-hoz való csatlakozás jelentik a fontosabb mérföldköveket a gazdaság fejlödésében és ezzel párhuzamosan az árstatisztikai munkákban is. Az egyes időszakokban más-más gazdasági területek, eltérő mutatók kerültek az érdeklődés középpontjába.

A történelmi, gazdasági korszakok változását a statisztika csak néhány éves késéssel tudta követni. Az első és a második világháború után a korábbi adatgyüjtések ellehetetlenültek, az új statisztikai adatgyüjtések tervezése, megvalósítása, az eredmények közlése hosszabb időt igényelt. Az 1968-as új gazdasági mechanizmusra és a 2004. évi EU-csatlakozásra többéves felkészülési idő után került sor, az árstatisztikában a váltás viszonylag gyors lehetett, de még így is zökkenőkkel járt. Fejlődési sza- 
kaszainak kijelölésénél, a szakaszok gazdasági-történelmi fordulópontokhoz kötésénél az átálás átmeneti időszakait is figyelembe kell venni.

Az árak müködő piacgazdaságban tudják betölteni értékmérő, a gazdaság szereplöit orientáló funkciójukat. A legnehezebb gazdasági helyzetekben áruhiány lépett fel, és a lakosság ellátását csak az árak kikapcsolásával, jegyrendszer bevezetésével lehetett megvalósítani. Magyarországon mindkét világháború alatt és a Tanácsköztársaság idején, valamint 1951-ben az élelmiszerek meghatározott körét csak jegyre lehetett kapni. A szocialista tervgazdaságban úgy gondolták, hogy az ármechanizmus kikapcsolásával is müködtetni tudják a gazdaságot.

A szerteágazó területeket lefedő 150 éves árstatisztika áttekintésénél kézenfekvő a folyamatosan és megbízhatóan megjelentetett statisztikai évkönyvek használata. Az árstatisztika hivatalon belüli súlyát, szerepét vizsgálhatjuk a megjelentetett, árakkal foglalkozó táblázatok számával, illetve az összes táblázaton belüli arányával. Bár meg kell jegyezni, hogy ennek a témakörnek a fontossága ily módon csak korlátozottan fejezhetö ki.

Az érték- és volumenindexek mellett gyakran nem jelentek/jelennek meg az évkönyvekben a háttérben használt deflátor árindexek. Egyes áradatokat, árindexeket az évkönyvön kívül jelentették meg. Így a külkereskedelmi árak alakulását részletesen feltáró elemzéseket és adat-összeállításokat a Statisztikai Közleményekben, majd 1923-tól 1942-ig a Statisztikai Szemlében publikálták. A mezőgazdasági árakról összeállított történelmi távú adatsorokról is ezekben a kiadványokban tudósítottak. Az 1970-es évektől számos szakstatisztikai évkönyv jelent meg, míg a legújabb időszakban a KSH internetes honlapján érhető el az adatok széles köre.

Egy közelmúltban megjelent tanulmány (Lencsés [2017]) szerint 1871 és 2015 között az árak altémakörben megjelent statisztikai évkönyvi táblázatok átlagos száma 9,51 volt. Ezzel a 25 altémakörből a 3. legalacsonyabbnak minősült. A legmagasabb táblázatszámot az ipar, építőipar érte el 45,30-dal, míg az áraknál alacsonyabb átlagos táblázatszámot a környezet és az energiagazdálkodás mutatta 8,02, illetve 7,31 táblázattal. Az árak altémakör átlagos táblázatszáma az évkönyvi táblázatok átlagos $(564,90)$ számának mindössze 1,70 százalékát tette ki.

A következö ábra jól mutatja, hogy mely években nőtt, illetve esett vissza az árstatisztikai témájú táblázatok száma. Az okokat és a táblázatok tartalmát a következőkben részletesebben kifejtjük.

Az ábrán mindössze két olyan év található, amikor nulla értéket mutat az évkönyvben megjelent árstatisztikai táblázatok száma (lásd az ábrát), a nagyobb történelmi megrázkódtatásokat követően, a statisztikai munka stabilizálása után az új területi, gazdasági rendnek megfelelően a több év adatát visszamenőleg közölt évkönyvekben szereplő árstatisztikai táblázatok száma található. Így az 1916-1918 évekről az 1924-ben megjelent, az 1919-1922-ről az 1925-ben, 1923-1925-ről az 1927-ben, 1943-1946-ról az 1948-ban, 1949-1955-ről az 1957-ben kiadott évkönyvek adatai szerepelnek.

Statisztikai Szemle, 96. évfolụam 7. szóm 709-741. oldal 
A statisztikai évkönyvekben megjelent árstatisztikai táblázatok száma

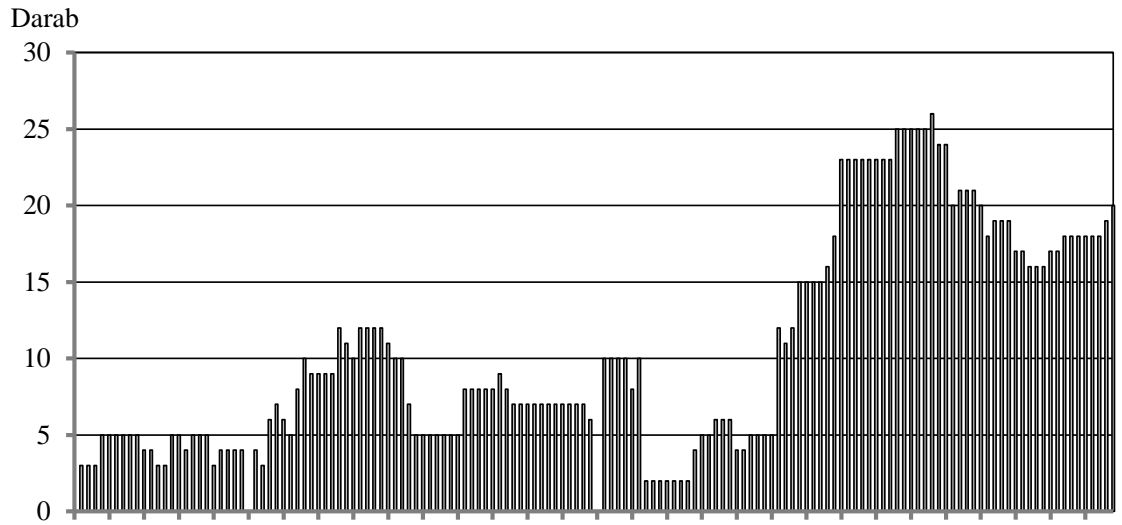

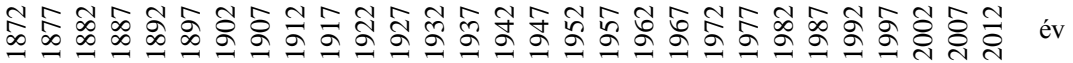

Megjegyzés. A statisztikai évkönyvek tárgyévei és nem a megjelenés éve szerint. 1892-ben nem jelent meg az évkönyv, 1942-ben a megjelent évkönyvben nem közöltek áradatokat.

Forrás: Saját gyüjtés a hivatalos statisztikai évkönyvekből.

Néhány év tekintetében 1-2 táblával több az itt közölt árstatisztikai táblázatok száma, mint Lencsés [2017] cikkében. Az eltérés abból adódik, hogy a szerző idesorolta azokat az általános, összefoglaló (például hosszú távú idősorokat közlő) táblázatokat is, melyekben a fogyasztóiár-index csak 1 oszlopot kapott, illetve azokat a korai szakmai (mezőgazdasági, bányászati) táblázatokat, melyekben a mennyiségi és értékadatok mellett nem önálló táblázatban jelentek meg az árinformációk.

A hivatalos árstatisztika történetét a következő szakaszokra bonthatjuk: 1. a kezdetek (1867-től az 1920-as évek közepéig); 2. az árindexszámítás kezdetei (az 1920-as évek közepétől 1950-ig); 3. a szocialista tervgazdálkodás időszaka (1950-től 1968ig); 4. az új gazdasági mechanizmustól a rendszerváltásig (1968-tól 1989-ig); 5. a rendszerváltástól az EU-csatlakozásig (1989-től 2004-ig); 6. az EU-csatlakozástól napjainkig (2004-től 2017-ig); 7. árstatisztikák napjainkban és a fejlesztés iránya.

\section{A kezdetek (1867-től az 1920-as évek közepéig)}

Az első szakasz történelmileg magába foglalja a kiegyezéstöl a monarchia felbomlásán, az első világháborún, az 1919-es tanácsrendszeren, a trianoni békediktátum utáni időszakon át egészen az 1924-1925. évi gazdasági stabilizációig tartó 
időszakot. Az árstatisztika szempontjából az érdeklődés középpontjában a mezőgazdasági termények, a bányászati, valamint a lakosság ellátásában fontos termékek árának dokumentálása állt.

Az első nagy összefoglaló árstatisztikai munkával a Budapesti Kereskedelmi és Iparkamara jelentkezett. Az 1873-as bécsi világkiállítás alkalmából összeállította a pesti piacon történt árjegyzéseket, s az eredményeket „Adalékok Magyarország terményeinek ártörténetének történetéhez a XIX. században" címü kiadványban jelentette meg. Ebben a munkában 1800-tól kezdve 1872-ig feldolgozták 21 cikk (búza, rozs, árpa, zab, kukorica, repce, repceolaj, gyapjú, bor, szesz, pálinka, dohány, bör, faggyú, szalonna, disznózsír, ágytoll, kender, gubacs, méz és viasz) árait a budapesti piacokon hétről hétre, illetve vásárról vásárra (Magyar Királyi Statisztikai Hivatal [1913]).

Már az „Országos Magyar Királyi Statistikai Hivatal” első kiadványai is tartalmaztak árinformációkat. A „Magyar Statistikai Évkönyv” első évfolyama az 1868-as tárgyévről szólt (előfordultak benne 1867. évi adatok is) és 1872-ben jelent meg.

Kezdetben nem volt külön áralakulással foglalkozó fejezet a statisztikai évkönyvekben. Önálló, csak áradatokat tartalmazó táblázatok a nagykereskedelmi és kiskereskedelmi területekről jelentek meg, ezen kívül a mezőgazdaság és az ipar termékeinek termelését természetes mértékegységben, valamint értékben közlő táblázatok némelyikén szerepelt áradat, illetve elszórtan néhány szolgáltatás díját is közölték.

Az első években többször változott az évkönyv fejezetekre bontása és benne az áradatok helye. Viszonylagos stabilitás az évkönyv 1893-as évről szóló átszerkesztett „új folyamától” számítható, ahol az őstermelés (ezen belül a mezőgazdaság), a bányászat és kohászat, valamint az ipar és kereskedelem fejezeteibe kerültek az árakat tartalmazó táblázatok.

Ebben az időszakban föként nagy- és kiskereskedelmi árakat jelentettek meg az évkönyvekben, bár akkor még nem így nevezték a „kicsinybeni” és „,nagybani” piaci, valamint tőzsdei árakról gyüjtött adatokat. A főbb termékkörök, amelyekről adatokat közöltek az évkönyvek, a következök voltak:

- „A nevezetesebb termények középárai a budapesti piaczon” címü táblázat az 1871-es tárgyévtől kezdődően. Az adatközlések először a búza, árpa, rozs, zab, kukorica, borsó, bab, lencse, köles, burgonya, hús, bor, sör, tüzifa, széna, szalma termékek nagybani eladási árait tartalmazták, a termékek köre a későbbi években már 115-137-re bővült. Egyes években $(1871,1872)$ havi és éves középárakat, más években a legmagasabb és legalacsonyabb árakat közölték. Az adatok 1915-ig érhetök el.

- Folyamatosan alakult a „Gabonanemüek ára a budapesti áru- és értéktőzsdén" címü táblázat közlési formája. Kezdetben a métermázsánkénti havi és éves átlagárakat, illetve legmagasabb és legalacso- 
nyabb jegyzési árakat publikálták (1881-től) a búza, rozs, árpa (maláta), árpa (takarmány), zab, kukorica termékekre. Néhány évre kiegészült a táblázat a káposztarepce, köles, disznózsír, szalonna, szilva, szilvaíz, heremag termékekkel.

- Az állatvásárokon a 10-10 legnagyobb országos piacon (a nagyobb városokban) elért legmagasabb és legalacsonyabb darabonkénti eladási áradatok jelentek meg táblázatban: a szarvasmarha 11-féle, a ló 10-féle, a juh 6-féle, a sertés 3-féle minőségi kategóriában. A sertés átlagárakat 1892-ig visszamenőleg közlik, a többi adat 1900-tól érhető el.

- Külön táblázatokban jelentették meg 1900-tól „A kőbányai sertésforgalom és sertésárak”, „A budapest-ferencvárosi konzumvásár sertésforgalma és napi átlagárak”, valamint a „Budapesti gyapjú aukciók" áralakulásának adatait.

- Mai értelemben vett kiskereskedelmi áraknak tekinthetők „A közönségesebb szükségleti tárgyak árai Magyarország főbb piacain” címü adatközlések 1878-tól. (A fontosabb termények: búza, rozs, árpa, zab, kukorica, borsó, bab, lencse, köles, tatárka, burgonya, hús, bor, sör, tüzifa, széna, szalma.)

- 1894-től a táblázat „A fontosabb termények és háztartási fogyasztási cikkek évi átlagárai a kisforgalomban" címüre változott és tartalma is gazdagodott. A táblázat 1914-tôl „A fontosabb termények és egyéb fogyasztási cikkek évi átlagárai a középminőség figyelembevételével a kisforgalomban, némely főbb piacon (a fogyasztási adó beszámításával)" címüre módosult és tartalma 93 termékre bővült. Kezdetben a budapesti és vidéki városi adatok közös táblázatban szerepeltek, majd a közlés különvált két táblázatra.

Mai szemmel érdekesnek tủnik, hogy a termékek piaci árával együtt gyüjtötték, és azonos évkönyvtáblázatokban szerepeltették a napszámdíjak alakulását megyénként, illetve városonként havonta külön férfiakra, nőkre és gyermekekre, ellátással vagy anélkül. A gyermeknapszám 1893-tól kikerült a közlésből, és a napszámot aratás, cséplés, kaszálás, szőlőmunka, egyéb mezei munka, igásnapszám és fuvar tételekre bontották.

Az áradatok egyrészt más szervezetek (például kamarák, tőzsdék) által vezetett feljegyzések átvételéből, másrészt saját adatgyüjtésből származtak. A KSH már 1872-től megindította a rendszeres piaciár-statisztikai adatfelvételt.

Az adatgyüjtés induláskor 36-43 fontosabb nagyvárosi piacot ölelt fel. A termények száma kezdetben 14 volt (búza; rozs; árpa; zab; tengeri; borsó; bab; lencse; burgonya; marha-, borjú-, juh- és sertéshús; bor; tủzifa; széna és szalma). Megfigyelés alá csak a „kisforgalom” esett, és az árjegyzések szélsőségeit (legalacsonyabb és 
legmagasabb ár) „tudakolták”. Az adatszolgáltatók a rendőrkapitányságok voltak, és az adatokat havonta küldték meg a statisztikai hivatalnak. A piaci statisztikát a hivatal 1894-ben és 1899-ben bővítette. A városokon kívül a nagyobb forgalmú piaccal és a katonai helyőrséggel rendelkező községeket (összesen 299 települést) is kijelölték adatszolgáltatásra. A kimutatás XV föcsoportban 146 fontosabb közszükségleti cikkre bővült. A legmagasabb és legalacsonyabb áron túl az átlagárat is összeírták (Magyar Királyi Statisztikai Hivatal [1913]).

Az 1897-ben átadott Budapest fövárosi Központi Vásárcsarnok szinte a kezdettől gyüjtötte a csarnoki árakat és ezeket közre is adta. E közlemények fontos adatforrásai voltak a hazai árstatisztikának.

Piaci árakat - változó tartalommal - összeírói segítségével azóta is gyüjt a hivatal. Publikálásuk a mezőgazdasági árak, a kiskereskedelmi árak, illetve a fogyasztói árak között történik, valamint szükségesek a megfelelö árindexek számításához.

A mezögazdaság témakörében részletes adatokat közölt az évkönyv az első évfolyamától kezdve a szüret eredményei táblázatokon belül a szőlö-, must-, bor- és aszúbor „becs- és eladási áráról” 1861-ig visszamenőleg, megyénként és országosan, majd a bort 1879-től megbontották lehúzott újborra, közönséges óborra és finom csemegeborra.

Az 1907. évi évkönyvben megkezdődött a dohány beváltási árának vármegyénkénti közlése is (1905-ig visszamenőleg).

Az ipari termelői árak előfutárának tekinthető a bányászati és kohászati termékek áráról (1863-ig visszamenőleg) évenként bányakapitányságonként a mennyiségi és értékadat mellett közölt „középár a termelés színhelyén” adat. Kezdetben 41 termékre (köztük aranyra, ezüstre, rézre, nyersvasra, feketekőszénre, barnakőszénre) bányászott ércre, ásványra terjedt ki az adatközlés, majd számuk 1891-től 51 termékre nőtt. A termékeket megbontották készárura és feldolgozott nyerstermékekre, és a bányászati termékek kiegészültek kohászati (például öntött nyersvas), valamint vegyipari (például kén, timsó, ásványfesték) termékekkel is.

Az évkönyv első évfolyamában a sótermelés mennyiségén és pénzértékén túl a „bányáknál vagy teljes vagy kedvezményi árat” is publikáltak (az 1868-1870. évekre), de az árközlés a második évfolyamtól elmaradt.

Bár más ipari árakat ebben az időszakban nem közöltek, az 1899. évben végrehajtott iparstatisztikai adatgyüjtés eredményeként 163 termékre publikálták a termelés mennyiségét és értékét (ezer koronában). A homogén termékekre ezekböl az adatokból egységértékeket lehetett számolni.

A szolgáltatásokról megjelent adatok között is található néhány árinformáció. Például 1868-tól 1875-ig a feladott sürgönyök díjazási egységének adata is megjelent az évkönyvekben.

Különlegesnek tekinthetö a külkereskedelemi árak helyzete. Az évkönyvek a behozatalban és a kivitelben „Nevezetesebb áruk forgalma” táblázatban közöltek ter- 
mékenként, termékcsoportonként mennyiségi és értékadatokat az 1868-as tárgyévtől kezdődően. A behozatal 44 termékcsoportján belül a nagyobb értéket a nyersanyagok, vas- és acéláruk, fémáruk, jármüvek, müszerek, gépek képezték, míg a kivitelben a mezőgazdasági termékek (búza, rozs, zab, kukorica, liszt, sertés, bor, gyapjú) domináltak.

Bár a KSH külkereskedelmi árakat, árindexeket az évkönyvekben egészen az 1970-es évekig nem közölt, már 1906-tól megjelentette az értékmegállapító bizottság részletes szöveges elemzéseit, jelentéseit a fontosabb termékek, termékcsoportok külkereskedelmi forgalmáról, az árak alakulásáról, és meghatározta az egységértékeket (Magyar Királyi Statisztikai Hivatal [1911]). A külkereskedelmi árak alakulásáról szóló jelentést 1906-tól a Statisztikai Közleményekben, majd 1923-tól 1942-ig a Statisztikai Szemlében tették közzé.

A külkereskedelmi forgalom egyenlegének és az egyes termékek áralakulásának fontosságára való tekintettel, a hivatalon belül 1906-ban létrehozták a Magyar Áruforgalmi Statisztikai Állandó Értékmegállapító Bizottságot azzal a céllal, hogy a magyar szentkorona országainak külkereskedelmi forgalmáról termékcsoportonként - az árulajstrom minden tételénél - jellemezze a behozatal, valamint kivitel alakulását és az árképzésre befolyásolással bíró tényezőket, s határozza meg és indokolja az egységértékeket. A mennyiségi adatokból az egységértékek segítségével állították elő az értékadatokat, majd a külkereskedelmi egyenleget. Az első bizottság megbízatása 1918-ban lejárt, majd 1922-ben a visszamenőleges adatok előállításának kötelezettségével és kibővült feladatkörrel (a külkereskedelmi árak mellett a belföldi nagykereskedelmi árak elemzését is bevonva) újjászerveződött a bizottság a vámtarifa osztályainak megfelelő szakosztályokba. Elnöke a statisztikai hivatal igazgatója, tagjai a fővámigazgató, a gazdasági minisztériumok és a kamarák kiküldöttei, szakértôi az ipar, valamint a kereskedelem köréből kinevezett szakemberek voltak.

Jelentős fordulatot idézett elő a hivatalos statisztikában az első világháború vége és a trianoni békekötés. A békediktátum következtében jelentősen csökkent az ország területe, és új feltételek között kellett újjáépíteni a szakstatisztikákat is. A felmerült nehézségek következtében több évig szünetelt az évkönyvek megjelenése, így az áradatok publikálása is.

\section{Az árindexszámítás kezdetei (az 1920-as évek közepétől 1950-ig)}

Az árak iránti növekvő érdeklődés hatására külön „Áralakulás” fejezetet vezettek be az 1925-ben kiadott, az 1919., 1920., 1921., 1922. évekről együttesen számot adó 
statisztikai évkönyvben. Itt kaptak helyet a korábbiakhoz képest jelentősen csökkentett tartalmú adatközlések.

Az első világháború elötti évkönyvek 10-12 táblázataihoz képest az árstatisztikai adatközlések száma 5-re esett vissza. A nagykereskedelmi, tőzsdei árak táblázataiból fennmaradt 1 . „A gabonanemüek átlagos ára a budapesti árú- és értéktőzsdén, illetőleg azok maximális árai 1913-tól 1922-ig”; 2. „A budapesti sertés-átlagárak 1920-tól 1922ig”; 3. „A budapesti gyapjúpiac áralakulása 1921-ben és 1922-ben”; valamint a kiskereskedelmi árak táblázata 4. „A fontosabb közszükségleti cikkek ára, a középminőség alapul vételével, a kisforgalomban, némely föbb piacon 1921-ben és 1922-ben”.

Az árindexszámítás előfutárának tekinthető, hogy megjelent az 5. „Egy munkáscsalád heti élelmezési szükségletének költségei 82.800 kalóriát képviselő élelmiszerek alapján koronákban és index-számokban 1914-től 1922-ig" megnevezésủ táblázat.

Az 1927-ben kiadott (1923., 1924., 1925. évek adatait tartalmazó) évkönyvben már két koncentrált információtartalmú mutatót vezettek be: a létfenntartási költségek indexszámát és a nagykereskedelmi árak indexszámát külön Budapestre és vidékre, ahol vidék alatt a nagyvárosokat értették. A következő években a termékártáblázatok összetételét is e két mutató számításához igazították. Külön közölték a budapesti és vidéki nagyvárosi nagykereskedelmi (nagybani piaci), valamint kiskereskedelmi adatokat, az indextáblázatok termékcsoportjainak részletes bontása szerint.

\subsection{Létfenntartási költségek indexszámai}

Az első világháború utáni inflációs években a fogyasztási cikkek árainak rohamos drágulása a létfenntartási költségek alakulására irányította a figyelmet. Ezzel magyarázható, hogy 1921-ben - szinte egyidejüleg - három olyan szintetikus árindex számítása kezdődött el, amelyek a legfontosabb fogyasztási javak árszínvonalának alakulását mutatták: 1. A Pester Lloyd (budapesti német nyelvü napilap) 1921 elejétől 1944-ig havonta közölte a kiskereskedelmi árak indexszámait. 2. A Szakszervezeti Értesitő 1921-ben kezdte meg a létfenntartási költségindexszámok közzétételét Gál Benö sémája alapján. Ez a számítás 1943-ig maradt fenn. 3. A Közgazdasági Figyelöben ugyancsak 1921-ben kezdödött meg a létfenntartási költségindexszámok közzététele Dálnoki Kováts Jenö módszere alapján. Ezek az indexszámok később a Magyar Ipar címú havi folyóiratban jelentek meg, egészen 1942-ig (Zafir [1991]).

A statisztikai hivatal 1924-ben jelentette meg a szélesebb szükségleti csoportokra végzett számításának eredményeit először a Magyar Statisztikai Szemlében, majd 1927-ben már a módszertanilag egységesített, 1924 és 1926 közötti létfenntartási költség indexszámait lakásbérrel és lakásbér nélkül papírkorona- és aranykoronaalapon (1913 = 1 bázison) a statisztikai évkönyvben is. 
Kiindulásként a KSH módszerénél egy négytagú munkáscsalád szükségleteit vették figyelembe. A család családfőből, feleségből, 12 éves fiúgyermekből és 6 éves leánygyermekből állt. Mivel az induláskor háztartás-statisztikai adatfelvételek még nem álltak rendelkezésre, a szükségleteket elméletileg határozták meg. A szükségleteket felosztották élelmezésre, ruházatra, fütésre és világításra, valamint lakbérre. E csoportokban a legjellemzőbb és legkevesebb számú átlagos árakat vették figyelembe. Az élelmiszereknél a napi kalóriaszükségletből indultak ki, ami a családfö esetében 3500 , a feleségé 3150 , a 12 éves fiúgyermeké 1800 , a 6 éves leánygyermeké $1500 \mathrm{kcal}$ volt. A fehérje-, zsír- és szénhidráttartalomra is figyelemmel meghatározták a család heti szükségletének kielégítéséhez szükséges fontosabb termékek körét és mennyiségét (marhahús, sertéshús, zsír, tej, tojás, sajt, kenyér, liszt, burgonya, káposzta, bab, cukor). Az élelmiszerárakat a csarnoki jelentésből vették, a fogyasztó által ténylegesen a hónap utolsó napján fizetett ár szerint. A ruházati termékkörben a felsőruha (férfi, női, fiú, leány), fehérnemü (férfiing, férfi alsónadrág, női ing), harisnya (férfi, női, gyermek), cipő (férfi, női, gyermek) termékeket tartották jellemzőnek. A fütés és világítás csoporton belül a szén, tüzifa és villany árát, a lakbérnél a szobakonyhás lakás heti bérét vették figyelembe. A termékek kiválasztásánál a német gyakorlatból indultak ki, ahol összesen 33 terméket (ebből 15 ruházatit) vettek számításba. Az indexek bázisául az első világháború előtti, 1913. évi átlagos költségek szolgáltak (Statisztikai Szemle [1925]).

A kezdeti módszertant folyamatosan finomították. A gazdasági helyzetnek megfelelően növelték, illetve a háborús években csökkentették a kalóriaszükségletet, aktualizálták, bővítették a figyelembevett termékek körét.

Az (1949-ben megjelent) 1947. évi évkönyvtől a kiskereskedelmi adatok már forintban értendők, és az „Egy budapesti négytagú munkáscsalád létfenntartási költségei indexszámokban”, valamint emellett egy újabb, az „Egy vidéki négytagú munkáscsalád létfenntartási költségei indexszámokban (1946. IX. havi vidéki átlagöltség = 100)" címü táblázat és e kettő összesített adataiként az „Egy négytagú munkáscsalád létfenntartási költségei országos átlagban" címü táblázat is megjelent. A vidéki indexet 17 vidéki város havonkénti létfenntartási költségeinek, a lakosság számának figyelembevételével mérlegelt (súlyozott) átlaga alapján számították, az országos átlagot a 17 vidéki város és Budapest lakosságszámának mérlegelt átlaga alapján határozták meg.

\subsection{A nagykereskedelmi árak indexszámai}

Az 1927-ben kiadott statisztikai évkönyvben, elöször jelent meg a „Nagykereskedelmi árak indexszámai” címủ táblázat is. Ez volt az első olyan átfogó a mutató, melynek módszertanát a KSH önállóan dolgozta ki. A hivatalon belül a 1920-as évek 
elején elindult módszertani munka azért fókuszált a nagykereskedelmi árindexekre, mert általuk a gazdaság nagyobb részéről lehetett átfogó információkat biztosítani.

A nagykereskedelmi árindex kidolgozásánál célul tüzték ki, hogy a termelés, a fogyasztás és a forgalom összes fontosabb területéről szerepeljenek benne áruk úgy, hogy ugyanakkor a termékek száma ne legyen kezelhetetlenül nagy. Az árindexszámítás módszerének főbb szempontjai: 1 . Az adatokat túlnyomó részben a Kereskedelmi Statisztikai Értékmegállapító Bizottság tagjai és szakértői szolgáltatták, a gabonánál és korpánál a tőzsdei, egyes termékeknél a csarnoki nagyforgalom árait vették figyelembe. 2. Nem havi átlagárakat használtak fel, hanem - szoros minőségi körülhatároltsággal - a hónap utolsó napján ténylegesen fizetett árakat. 3. A budapesti piacra vonatkozó papírkorona-árak tartalmazták az adókat és a kincstári árrészesedést. 4. Tekintettel arra, hogy a termékekre vonatkozó súlyadatok nem álltak rendelkezésre, és becslésekre nem akartak hagyatkozni, az indexek súlyozás nélkül készültek (Szönyi [1924]). A magyar nagykereskedelmi árak indexszámait a KSH 1923. december 31-től számította. Az index számításához kezdetben 54 árjegyzést használtak fel.

A „Nagykereskedelmi árak indexszámai a hónap végén” című évkönyvi táblázatban az összes áruk, élelmiszerek és mezőgazdasági termékek, az ipari anyagok és termékek, a nyersanyagok, gyártmányok termékcsoportokat közölték, és megbontották az összes terméket belföldi és külföldi árukra. Az első adatközlés az 1923 decembere 1925 decembere közötti hónapokra vonatkozott, és bázisévként 1913-at használták.

Az indexszámok új sorozatát a hivatal 1939-ben vezette be úgy, hogy a közlendő adatokat 10 évre visszamenőleg állították elő. Az új index számítása a korábbinál több mint tízszer nagyobb számú (548) árjegyzés alapján történt. A termékáradatoktól a fốcsoportindexekig úgy építették fel a számításokat, hogy több lépésben szakmai koefficiensekkel mérlegelték (súlyozták) a részindexeket. Változott az évkönyvi táblázatok felépítése: az összes áruk, ebből a mezőgazdaság és állattenyésztés termékei, a mezőgazdasági ipar termékei, a gyarmatáruk, az ipari anyagok és termékek körébe tartozó áruk árainak indexszámát közölték (Szőnyi [1939]).

Az évkönyv nemzetközi táblázatai 1926 és 1941 között mind a létfenntartási költségek indexszámait, mind a nagykereskedelmi indexszámokat 30-40 országra közölték.

A Statisztikai Szemlében 1926 és 1931 között rendszeresen szöveges elemzést közöltek az árstatisztikai jelzőszámokról. Ismertették a legújabb adatokat, tendenciákat a nagykereskedelmi árak, a nagykereskedelmiár-index, a kiskereskedelmi árak és a létfenntartásiköltség-index témában.

Az első világháború utáni évekre, az 1920-as évek első felére a rendkívül rossz gazdasági helyzet és az igen nagymértékü infláció volt jellemző. 1925-1926-ban, amikor az infláció a legnagyobb mértéket öltötte, a papírkoronaárak mintegy kétszázszor voltak magasabbak, mint a háború előtt. Az 1927-től megvalósult stabilizáció és a pengő bevezetése konszolidálta a helyzetet (Marton [1979]). Az 1929 és 
1933 közötti gazdasági világválság általános árcsökkenéssel járt, de különösen a mezögazdasági termékek, ezen belül is a növények ára csökkent drasztikusan. A növényi termékek ára 1933-ban 32, az állati termékeké 56 százaléka volt az 1928. évinek. Az agrártermékek árának jelentős visszaesése az ipari termékek árindexéhez képest az agrárolló ${ }^{1}$ jelentős nyílását jelentette.

Az 1938. évi első bécsi döntéssel visszacsatolt felvidéki területek, majd az 1940. évi második bécsi döntés alapján visszatért kelet-magyarországi és erdélyi terület, valamint Kárpátalja adatainak begyüjtése nehéz feladat elé álította a hivatalt. Takarékossági okok miatt az 1941. évről kiadott évkönyvből kimaradtak a nemzetközi táblázatok.

A második világháború befejeztével Magyarországon példátlan méretủ infláció alakult ki: az 1946 július végén forgalomban levő pengő az 1938. évi pengőérték 400 kvadrilliomod $\left(10^{24}\right)$ részét „érte”. A stabilizációs program végrehajtása után 1946. augusztus 1-jével vezették be a forintot. Az átállásnál központilag határozták meg az árarányokat. A pengő/forint szorzó az élelmiszereknél 5,48, a ruházati termékeknél 6,56, az energiahordozóknál 3,58, a lakbéreknél és szolgáltatásoknál 1,26 volt. Az 1946-os árak nem sokáig éltek, ismét beindult a gyors infláció az élelmiszerhiány miatt, és az ipar nem volt képes még az alapvető szükségletek kielégítésére sem. A háborús időszakban és 1951-ben ismét szükségessé vált a jegyrendszer bevezetése.

A legtöbb statisztikai idősor összeállításánál kihívást jelentett Magyarország 1947 elötti területi és hivatalos belföldi fizetőeszköz-változásának kezelése. Tekintettel arra, hogy a nagykereskedelmi adatokat jelentős részben a tözsdén, illetve a nagybani vásárokon, aukciókon, míg a kiskereskedelmi adatokat Budapest, valamint a nagyobb városok piacain gyüjtötték, a területi változások az áradatokat kevésbé érintették. Más a helyzet a fizetőeszköz-változásokkal. Kezdetben az árakat „osztrák értékü forintban és krajcárban" közölték, majd 1892 és 1926 között koronában, 1927-től pengőben, 1946. augusztus 1. után forintban. (Az átmeneti időszakokban a statisztika párhuzamosan használt arany- és papírvalutákat.) Külön kihívást jelentett az infláció, különösen az 1946. évi hiperinfláció kezelése. A változásokat követően az átállás új pénznemre és a hosszabb visszamenőleges idősorok átszámítása új fizetőeszközre jelentős erőforrásokat igényelt a hivataltól.

A második világháború okozta hosszabb szünet után 1948-ban jelent meg az 1943, 1944, 1945, 1946 évek adatait bemutató évkönyv. Ennek „Áralakulás” címü fejezetében a korábbi rendnek megfelelően közölték még a tőzsdei, nagykereskedelmi és kiskereskedelmi árakat, valamint a két index táblázatait. A létfenntartási költség indexszámait 1945-1946-ra arany- és papíralapú valutában vagy százalékban (1946. szeptember $=100$ alapon) számították.

\footnotetext{
${ }^{1}$ Az agrárolló az árolló egyik formája, mely a mezőgazdasági és az ipariár-index növekedésének egymáshoz viszonyított helyzetét mutatja. Az agrárolló nyílásáról akkor beszélünk, amikor a mezőgazdasági termékek árai kevésbé nőnek (vagy jobban csökkennek), mint az ipari termékeké, és így a mezőgazdasági termelők által megtermelt érték egy részét elvonják az ipar javára.
} 
Az 1950-ben megjelent „Statisztikai évkönyv 1948” átmenetet képez a régi és az új típusú adatközlések között. Még megjelentek a régi típusú adatgyüjtések eredményei (nagybani árak Budapesten; fogyasztói árak Budapesten; nagybani árak indexszámai; egy budapesti, egy vidéki és egy (országos) 4 tagú munkáscsalád létfenntartási költségének indexszámai), emellett új jelenségként, részletes adatokat közöltek a gyári eladási árak alakulásáról (75 termékre) és a gyári eladásiár-indexek iparcsoportonkénti alakulásáról (1947-1948-ra). Átmenetileg visszatért a nemzetközi áralakulást bemutató „Árak alakulása a világpiacon” című táblázat is 46 termékkel.

\section{A szocialista tervgazdálkodás időszaka (1950-től 1968-ig)}

Új árrendszert dolgoztak ki 1949 végén, 1950 elején, melyben mind a termelői, mind a fogyasztói árakat központilag rögzítették (ezek voltak az ún. hatósági árak), és azokat 1951 decemberében léptették életbe, egyidejüleg megszüntetve az 1951 elején ismét bevezetett jegyrendszert. A termékek, szolgáltatások országosan egységes árjegyzéki árait, illetve az aktuális változásokat az árhatóság a hetente, havonta megjelenő árközlönyökben rendelte el.

A piaci folyamatok kikapcsolása, a központi árképzés mellett az árak változásának követése egyszerübbé vált, de közgazdasági tartalma kiüresedett. 1952 és 1957 között, ugyan alig volt árszínvonal-változás, azonban a rögzített hatósági árak mellett mind élesebben jelentkezett a burkolt áremelés és az áruhiány.

A szocialista tervgazdálkodás bevezetése jelentősen visszavetette a legtöbb szakstatisztikát, köztük az árstatisztikát is. Az évkönyvekben megszünt az áralakulással foglalkozó fejezet, és minimálisra csökkent az árakat tartalmazó táblázatok száma. A figyelem központjában a tervek teljesítésének mérése állt. Új, volumenindexeket tartalmazó táblázatok jelentek meg az évkönyvben, árindexek nélkül: „Az ipari termelés volumenének indexe”, „A mezőgazdasági össztermelés értéke változatlan áron”, „A kiskereskedelmi eladás volumenének alakulása”.

Kialakult a KGST-országokban (Kölcsönös Gazdasági Segítség Tanácsa) alkalmazott ún. „árjegyzéki módszer”, mely arra épült, hogy az árjegyzéki árakhoz a statisztikusok utólag rendeltek súlyokat, valamint a változatlan és megváltozott áron kalkulált aggregátumokból számították ki a - legtöbbször háttérben használt, nem publikált - árindexeket.

Az árstatisztikai adatok közlése az 1954-ben megjelent, visszamenőleges adatokat is közlő évkönyvben a „Piaci átlagárak cikkenként Budapesten és a megfigyelt 39 városban 1952-ben és 1953-ban” (17 termékre) táblázatra korlátozódott. 
Az árak iránti érdeklődés kielégítésére az évkönyvön kívül megjelentették „Az áralakulás Magyarországon 1938-ban és 1945-1955-ben” címủ tanulmányt az 1957ben kiadott Statisztikai Időszaki Közleményekben ( $K S H$ [1957]). Az ipari és a mezögazdaság termelői árak, valamint a fogyasztói árak adatainak közlése mellett szöveges elemzésben kitértek az időbeli összehasonlítás módszertani problémáira is.

Az 1949-1955. tárgyévről szóló évkönyvben elöször jelent meg a „Munkások és alkalmazottak fogyasztói árindexe"2 táblázata (a kiskereskedelmi árak és piaci átlagárak táblázata mellett).

A létfenntartási költségek indexszámait felváltó fogyasztóiár-index számítását az tette lehetővé, hogy a hivatal 1949-től részletes háztartás-statisztikai adatfelvételeket hajtott végre. A háztartás-statisztikai adatok megbízható súlyrendszert szolgáltattak a munkások és alkalmazottak fogyasztóiár-indexe számításához. Az adatközlés 1964. tárgyévi évkönyvtől kiegészült a parasztság fogyasztóiár-indexével. A fogyasztóiárindex a lakosság által vásárolt fogyasztási cikkek és szolgáltatások árainak átlagos változását mutatta.

További előrelépés történt az 1956-ról kiadott statisztikai évkönyvvel. Visszatért a „Felvásárlás” című fejezeten belül a „Fontosabb mezőgazdasági termékek évi átlagárai (1949-1956)" táblázat, ahol beadási ár, szerződéses és szabad felvásárlási ár és együttes átlagár bontásban közöltek adatot 15 termékre.

A mezőgazdasági termelői árak számítása problematikus volt 1946-tól egészen 1956-ig a kötelező beszolgáltatások rendszere miatt. A begyűjtési árak nemritkán az előállítási költségeket sem érték el. Egyes termékeknek egyidejűleg három, egymástól igen eltérő ára volt. A termelői átlagárat 1 . a kötelező állami beszolgáltatási ár, 2 . az állami szabadfelvásárlási ár és 3. a szabadpiaci ár súlyozott átlaga adta. 1957-től a szerződéses felvásárlási rendszerben már csak a két utóbbi piacformában bonyolódott a termékforgalom.

Bővült az adatközlés az 1957-ben megjelent évkönyvben a „Kiskereskedelmi árak és egyes szolgáltatások ára" táblázattal (33 élelmiszer, 63 iparcikk és 10 féle szolgáltatásra), ahol az 1938. évi adatot pengőben, az 1949 és 1955 közötti évek adatait forintban közölték, valamint a „Piaci átlagárak Budapesten és a megfigyelt 39 városban 1952-1955” táblázattal, melynek adatköre 46 féle cikk volt.

Érdekességként szolgál, hogy az 1950-es évek évkönyveiben az „Igazságszolgáltatás" címü fejezetben megjelent az árdrágítás miatt jogerősen elítéltek száma, mely 1951-ben volt a legmagasabb 5333 fövel (ez az adat korábban 1938-ban még csak 64, 1950-ben 3012 fö, majd csökkenő számú, 1956-ban 2820, 1957-ben 1500 fö volt).

Az 1950-es években indult el a KSH-ban az árindexek szélesebb körének számítása. A hivatalon belül az árindexszámítás elméleti, módszertani kérdései körül vita bontakozott ki. Ellentétben a szocialista (szovjet) dogmatikus megközelítéssel, kor-

\footnotetext{
${ }^{2}$ Az idézet címeknél meghagytuk az eredeti írásmódot.
} 
szerü érveken alapuló, nyílt szakmai vita alakult ki, aminek eredménye 1958 elején kollégiumi határozatban is megjelent.

A határozat lényege:

1. A KSH az árváltozások mérésére, általános alapelvként a láncmódszerrel képzett Fisher-indexet alkalmazza. (A Laspeyres- és Paasche-formula geometriai átlaga). Az ettől eltérő eljárásokat indokolni kell. A már közölt árindexeket nem kell felülvizsgálni. Az összekapcsolásokat szakszerüen, kellö tájékoztatás mellett kell elvégezni.

2. Időnként, általában ötévenként, meg kell vizsgálni, hogy milyen mértékü különbségek adódhatnak, s ellenőrzésként Laspeyres- és Paasche-típusú közvetlen bázisindexeket is kell számítani. A Fisherindex jobb érthetősége, felhasználhatósága érdekében - szükség esetén - publikálni is kell azokat.

3. Az 1958-ban konkrétan elvégzendő feladatok: Ezek között szó volt a mezőgazdasági, az ipari termelöiár-, a közlekedésiár- és a fogyasztóiár-indexek súlyozásáról is. Az akkor még előkészületi stádiumban levő külkereskedelmiár- és építőipariár-indexek súlyozásával kapcsolatban úgy foglaltak állást, hogy arról az egyéb módszertani kérdésekkel együtt kell dönteni (Statisztikai Szemle [1958]).

Egészen 1968-ig számították, de nem jelentették meg a KSH évkönyvekben a kiskereskedelmi, ipari termelőiár- és külkereskedelmiár-indexeket. Ezeket a hivatalban állították elő a rendelkezésre álló adatok alapján, és felhasználták a volumenindexek képzésénél, illetve nem nyilvános adatközlésben átadták a gazdasági vezetés számára.

„Az árjegyzéki árváltozások és az árváltozáskor külön megállapított súlyok segítségével készült a kiskereskedelmiár-index, amelyet ezek szerint módszertanilag az árváltozások teljes körü felmérésén alapuló módszerrel számított indexnek nevezhetünk." (Zafir [1968] 180. old). Az eklektikus, részint árhatósági közleményekre, részint vállalati jelentésekre, részint közvetlen ármegfigyelésekre építkező kiskereskedelmiár-statisztika ebben az időszakban szekunder jellegü volt.

Ez a fajta számítás nem mutatta ki a burkolt áremelések hatását (például amikor új néven drágábban hozták forgalomba a lényegében változatlan termékeket, vagy az árváltozás nem volt arányban a minőségi változással). Bár 1953-1954-ben a statisztikusok megpróbálták a burkolt áremeléseket is felmérni, azonban csak részsikereket értek el.

Mivel 1951 előtt az árváltozásokat nem rögzítették, ezért visszamenőleges idősort csak 1951-ig lehetett előállítani. 1951-röl például a kiskereskedelmiár-index számításához a nagykereskedelmi és ipari áruátadások termékenkénti értékadataihoz hozzá- 
adták a kiskereskedelmi hivatalos haszonkulcsot, és így képeztek kiskereskedelmi eladási árakat. Ezek továbbvezetése már a központi árintézkedések alapján történt (Balogh-Kapás [1953]).

Az ipari termelőiár-indexek számítása 1949 és 1954 között a 4-5 évre rögzített „tervárak” teljes körü megfigyelésére épült, 1955 és 1967 között az iparvállalatok teljes körủ megfigyelésén, a termékárak és árindexek idősorainak utólagos megállapításán alapult.

Az első, reprezentánsok (kiválasztott termékek) áraiból kiinduló árstatisztika a hivatalon belül a külkereskedelmiár-statisztika volt. A KSH vezetése 1958 közepén döntött a külkereskedelmiár-statisztika és árindexszámítás megszervezéséről, elindításáról. A folyamatos és rendszeres indexszámítás 1959-ben kezdődött, és ez az ármegfigyelési rendszer 1990-ig maradt fenn.

A külkereskedelmiár-statisztikát, az árindexszámítást az akkori külkereskedelmi áruforgalmi statisztika keretei között kellett megszervezni. A külkereskedelem állami monopólium volt, a statisztika a valamivel kevesebb mint 40 külkereskedelmi vállalat jelentéseire támaszkodott. Az adatszolgáltatás kötelező volt. Az árstatisztika a kijelölt reprezentáns termékek forgalmán alapult: a jelentések az exportált (importált) termékek értékét (határparitáson) és mennyiségét tartalmazták. Az indexek becslése koncentrált kiválasztással, reprezentatív minta alapján történt. A megfigyelt árreprezentánsok minőségi tulajdonságainak és jellemzőinak definiálásával a módszertan a „tiszta” árváltozások mérésére, egyúttal az összetételhatás kiszürésére törekedett. Ezek „unit value” (egységérték-) típusú árindexek voltak. Mivel mind a beszámolási, mind a bázisidőszak árai, mennyiségei rendelkezésre álltak, mód nyílt különböző súlyozású árindexek kiszámítására. Az indexformula tekintetében a KSH határozottan a Fisher-féle mellett állt ki. A külkereskedelem ún. kényes területnek számított. A számbavétel devizaforintban történt. A konvertibilitás hiánya miatt ezek az elszámolások (rubel, clearing dollár stb.) bonyolultak voltak, ami nagyon megnehezítette az eligazodást. Érthető, hogy az árak elemzése csak jelentős módszertani korlátok között, bonyolult feltételek mellett volt lehetséges. A különböző árucsoportok (élelmiszerek, anyagok, félkész- és késztermékek, gépek stb.) megfigyelése természetesen eltérő problémákat vetett fel, s így a reprezentáció mértéke, a minőségváltozás „kezelése” is eltérő volt. Összességében azonban a forgalom értékéből és mennyiségéből cikkelemenként kiszámított átlagárindexek jól jelezték az árváltozások tendenciáit, amit a későbbi vizsgálatok is alátámasztottak. Az 1950 és 1958 közötti időszakra az 1960-as évek második felében a forgalom adatai alapján visszamenőleg egységértékindexek készültek, összevontan a behozatali és a kiviteli forgalomra.

A korabeli viszonyok között korszerü külkereskedelmiár-statisztika indulásakor a magyar KSH a KGST-országok közül egyedül indult el a (nyugati) fejlett statisztikai tevékenység meghonosítása felé. Később a KGST-ben is igény mutatkozott a külkereskedelmiár-index iránt, s így 1960-ban, Prágában az az elvárás fogalmazódott 
meg, hogy minden ország a Paasche-formula szerint közöljön árindexeket, melyeket a KGST csak a szigorúan titkos évkönyvében publikált (Marton [1961]).

\section{Az új gazdasági mechanizmustól a rendszerváltásig (1968-tól 1989-ig)}

Fordulópontot jelentett az árak gazdaságban betöltött szerepében az 1968. január 1-jével indult új gazdasági mechanizmus. A reform egyik fontos eleme az árak részleges liberalizálása volt, vagyis a hatóságilag rögzített árak mellett egyes termékek árai a piaci keresletnek megfelelően alakulhattak. Az Országos Anyag- és Árhivatal utasításban szabályozta az egyes termékek árformába sorolását. (Árformák: I. rögzített, II. maximált, III. hatóságilag körülhatárolt keretek között alakuló, és IV. szabadon alakuló árak.) A reform irányelvei szerint a termelői és fogyasztói áraknak elsődlegesen a termelőket és a fogyasztókat kellett ösztönözniük gazdasági döntéseikben. Fokozatosan szükült a hatósági árszabályozás területe. A szabad áras termékek köre a bolti kiskereskedelmi forgalomban az 1970. évi 21-ről 1985-re 54 százalékra nőtt.

$\mathrm{Az}$ áttérés új helyzetet teremtett abban a tekintetben is, hogy az árindexszel szemben nagyobb lett az elvárás és kritikusabb a fogadtatás. Új igények jelentkeztek, és megváltozott az árindexszámítás statisztikai környezete is.

A KSH Kollégiuma a változásokra való felkészülés során, már 1965 decemberében foglalkozott az árstatisztika hivatalon belüli megszervezésével, és állást foglalt néhány főbb módszertani kérdésben is. „Az árstatisztika Hivatalon belüli megszervezése" címü határozata nyomán a hivatal egyes szakfóosztályain megindult a munka az új megváltozott helyzetnek megfelelő árstatisztikai rendszer kidolgozására is ( $\mathrm{Si}$ mon [1967]).

A szabadon alakuló árak megfigyelése a korábbi árstatisztika helyett meghatározóan közvetlen ármegfigyelésre épülö, önálló árstatisztikai rendszer kiépítését tette szükségessé, mely a KSH-tól jelentős többletkapacitást igényelt. Az új rendszerben a termelői árak esetében a KSH önálló vállalati adatgyüjtéseket alakított ki, míg a kiskereskedelmi (fogyasztói) árak tekintetében az árfelírási rendszer, az árfelíróhelyek (üzletek, szolgáltatóhelyek, piacok) és a reprezentánsok (kiválasztott termékek és szolgáltatások) kiválasztása egységes elveken alapult.

Az új helyzetben a statisztikai adatok már nemcsak a szük gazdasági vezetés számára készültek, hanem a nagyobb nyilvánosság számára is. Az 1968. évi adatokat tartalmazó statisztikai évkönyvben korábban nem látott mennyiségben (12 db) jelentek meg árstatisztikai táblázatok, köztük új árindex táblázatok. Az 1970-es és 1980as években tovább bővült a publikált árstatisztikák köre. Az 1980-as évek végére, 
1990-es évek elejére, a vizsgált 150 év maximumára 24-26 db-ra nőtt az árstatisztikai évkönyvtáblázatok száma.

Az 1968. évi évkönyvben újként közölték „A mezögazdasági termékek (fel)vásárlásának árindexe (1961-1968)" táblázatot - a növényi termékek, ezen belül: termények, zöldség, gyümölcs, bor; az állatok és állati termékek, ezen belül külön az állatok és az állati termékek, valamint összesen bontásban. Külön altáblában jelentek meg az állami felvásárlás, a piaci átlagárak és az ezeket együtt kezelő termelöi átlagárak árindexei.

Állami termelői (felvásárlási) ár alatt az állami és szövetkezeti átvevő vállalatoknak értékesített termékekért fizetett árat értették. Akkoriban a termelőszövetkezetek nagy tételben termeltek és értékesítettek az állami vállalatoknak, ahol vagy feldolgozták a mezőgazdasági termékeket, vagy a lakosságnak tovább értékesítették. A piaci termelöi ár a termelők piacon, általában kis tételben eladott termékeire vonatkozott. A mezőgazdasági termékek felvásárlásának, valamint a termelői átlagárának árindexét 84 termék, a piaciár-indexet 42 termék ára alapján számították.

Termékenként továbbra is megjelentették a mezőgazdasági termékek felvásárlási átlagárát (44 termékre), valamint a mezőgazdasági termékek piaci átlagárát (42 termékre). Külön táblázatban közölték az 1987. évi évkönyvtől kezdődően az agrárolló mutatóját.

$\mathrm{Az}$ „Ipar” címü fejezeten belül először „A szocialista ipari termelöi árindexei” táblázatok az iparcsoportok és a kiemelt iparágak bontásban jelentek meg. Majd néhány évvel később kibővült az adatközlés „A szocialista ipar értékesítési árindexei” táblázattal, értékesítési irányok (belföld, külkereskedelem, ebből rubel- és nem rubelelszámolású export) szerint.

Az ipari termelóiár-statisztika területén 1968-tól bevezették a reprezentatív adatgyüjtést, a külön árszintváltozási és deflátor árindexszámítást. Alapja a termelőiárindex esetében a forgalmi adó nélküli termelői ár, az értékesítésiár-index esetében a mindenkori eladási ár volt. A reprezentatív megfigyelésbe bevont termékek száma mintegy 3500 volt. Specialitást jelentett, hogy export árszintváltozási árindex készült külön a rubel-, valamint a dollárelszámolású exportra értékesített termékekre. Árindexet számítottak az iparágak tulajdonosi forma szerinti csoportosításán túl a minisztériumi, tanácsi, állami, szövetkezeti szektorra.

$\mathrm{Az}$ „Építőipar” című fejezetben az „Építőipari árindexek az építőipari vállalatoknál" táblázatban 18 építményfőcsoportra (utak, vasutak, lakóházak stb.) közölték az árindexeket, az összes építményekből kiemelve az új építményeket. Külön táblázatban jelentették meg az építőipariár-indexeket az építőipari vállalatok, építőipari szövetkezetek, építöipari közös vállalatok bontásban.

Magyarországon 1968 után kezdődött az építőipari áralakulás statisztikai megfigyelése. A módszer alapját a kötelező építési-szerelési árrendszer és az akkor érvényben levő norma- és árjegyzékek (az ÉKN [építési költségszámítási normák], az építőipari cikklista, a hatósági egységárgyüjtemények) képezték. Az építőipariár- 
statisztika az ÉKN-tételek leszámlázott árait figyelte meg, eleinte építkezéseket, később építőipari vállalatok számláit jelölve ki a megfigyelésre.

Az „Állóeszközök, beruházások” címü fejezeten belül az 1970. évi évkönyvtől (1968-ig visszatekintve) beruházásiár-indexeket közölt a KSH, egyrészt népgazdasági ágak (ipar; építőipar; mezőgazdaság; szállítás, hírközlés; kereskedelem; kommunális ágazatok, ezen belül lakás), másrészt anyagi-müszaki összetétel (építés, belföldi gép, import gép, egyéb) bontásban.

A „Belkereskedelem” fejezet „Kiskereskedelmi áralakulás” alfejezeten belül új táblázatot jelentettek meg „A kiskereskedelem árindexe árufócsoportonként” címmel 1961 és 1968 közötti évekre; az élelmiszerek és élvezeti cikkek, ezen belül a bolti forgalom, a vendéglátó forgalom és összesen; az iparcikkek, ezen belül a ruházati cikkek, a vegyes iparcikkek és összesen; valamint a kiskereskedelem összesen bontásban. Külön táblázatban jelent meg az „Idénycikkek árindexe a boltokban és piacokon” (baromfi, tojás, burgonya, zöldség-, fözelékfélék, hazai gyümölcs és összesen bontásban). Emellett publikálták a „Fontosabb idénycikkek átlagára a boltokban és piacokon” címü táblázatot (tojás, burgonya, sárgarépa, vöröshagyma, fejes káposzta, kelkáposzta, karalábé, paradicsom, zöldpaprika, alma, körte, szőlő termékekre). Az 1970. évkönyvtől új adatközlésként jelent meg az „Áralakulás a bolti kiskereskedelemben árformák szerint” (rögzített, maximált, szabad határok közötti és szabad ár bontásban).

Az új gazdasági mechanizmusra való felkészülés jegyében már 1966-ban megkezdődött a reprezentatív kiskereskedelmiár-statisztika megszervezése. A korábbi (számított, de az évkönyvben nem publikált) kiskereskedelmiár-indexben 1967-ig a hatóságiár-változásokat és az idénycikkes kiskereskedelmiár-változást vették figyelembe. Az 1968-ban indult adatgyüjtés az egész kiskereskedelmi hálózatból reprezentatív módon kijelölt 2200, viszonylag nagy forgalmú üzletben összeírt, a forgalomra jellemző termékek (reprezentánsok) árának megfigyelésére terjedt ki, és termékenként 50-100 üzlet adatait gyüjtötte be. Az üzletek és a reprezentáns termékek kijelölésénél úgy kellett eljárni, hogy egyszerre szolgálják a kiskereskedelmiár- és a fogyasztóiárindexek előállítását. A megfigyelt reprezentánsok egyedi árindexeiből kiskereskedelmiár-indexekhez árucsoportonkénti és területi részletezésben (Budapest, vidéki városok, községek), a fogyasztóiár-indexhez a fogyasztói kosaraknak megfelelő bontásban kellett összevont (csoport) árindexeket elöállítani (Marton [1968]).

A kiskereskedelmi árucsoportok indexei a tárgyévi forgalmi értékkel súlyozva, az áruföcsoportok és a kiskereskedelem összes forgalmának árindexei az előző évi forgalmi értékkel súlyozva készültek. Az egyes évekre vonatkozó indexekből láncindex módszerrel, azok szorzataként számították ki a bázisévhez viszonyított indexeket. A módszertan 1992-ig fennmaradt, időközben több mint 3 ezerre bővült a kiválasztott termékek és szolgáltatások száma, amelyet 120-130 csoportba rendeztek.

„A lakosság jövedelme és fogyasztása” fejezet „A fogyasztói árak” címü alfejezetén belül 1968-tól folytatódott a korábbi időszakban bevezetett „A munkások és al- 
kalmazottak fogyasztói árindexe”, „A parasztság fogyasztói árindexe”, valamint ezek összegeként „A lakosság fogyasztói árindexe” táblázatok közlése (kiadási föcsoportok szerint: élelmiszerek, élvezeti cikkek, ruházat, fütés, háztartási energia, egyéb iparcikkek és szolgáltatások bontásban). Az 1970-es években a fogyasztóiár-indexet főbb népességcsoportonkénti (munkásosztály, szövetkezeti parasztság, kettős jövedelmüek, nem fizikai foglalkozásúak, szellemi foglalkozásúak, nyugdíjasok és lakosság összesen) bontásban is közölték. Majd átalakult az adatközlés az 1980-as évek végére társadalmi rétegek (aktív háztartások, ebből budapestiek és vidékiek, gyermek nélküliek, egy-, kettô-, valamint három- és annál több gyermekes háztartások, inaktív háztartások, ebből budapestiek és vidékiek) szerinti bontásúra.

Az első modern, reprezentatív fogyasztóiár-statisztika a gazdaságirányítási rendszer 1968. évi reformjához kapcsolódott és 1992-ig nagyjából csak kisebb változtatásokon ment át. Ebben az időszakban a fogyasztóiár-statisztika szekunder típusú volt, más statisztikák (elsősorban a kiskereskedelmiár-statisztika) megfigyelési eredményeit gyüjtötte össze. Mivel az árfelírás a javaknak csak egy részére terjedt ki, a többit a vállalatok árjelentései alapján, illetve a hatósági árak esetében továbbra is árjegyzékből számították.

Ebben az évkönyvi fejezetben jelentették meg a „Kiskereskedelmi árak és szolgáltatási díjak" címü táblázatokat is. Az 1970-es években ezt megbontották külön „Kiskereskedelmi árak” (148 termék) és „Energia és egyes szolgáltatások díja” (11 termék) táblázatra, ahol 1975-től éves átlagárakat közöltek. Tovább bővült az 1980as években az adatközlés a „Lakosság részére végzett fogyasztói szolgáltatások árindexei”, valamint az „Egyes fogyasztási szolgáltatások díja” (10 szolgáltatásra: férfi hajvágás fazonra, kilósmosás, férfiöltöny-tisztítás, nőicipő-sarkalás, férfizakókészítési fazondíj, nőinadrág-készítés, 1 tekercs $24 \times 38$ mm-es fekete-fehér film előhívási díja, kvarcóra-elemcsere, $1 \mathrm{~m}^{2}$ falburkolat-készítés, gázkonvektorfelszerelés) táblázattal.

Elöször az 1970. évi évkönyvben jelent meg „A külkereskedelmi forgalom árindexe" címü táblázat, melyben a behozatalt és kivitelt szocialista országokra és nem szocialista országokra bontották, és közölték a cserearány-mutatót ${ }^{3}$ is $(1965=100$ bázison). Később a bontás rubel-, nem rubelelszámolásokra, valamint KGSTországok, fejlett és fejlődő országokra módosult. Az 1970-es évek végétől kiegészült az adatközlés az „Árindexek áruszerkezeti csoportosítás szerint” táblázattal, melyben 5 részre bontva (energiahordozók, villamos energia; anyagok, félkész termékek, alkatrészek; gépek, szállítóeszközök, egyéb beruházási javak; fogyasztási iparcikkek; élelmiszeripari anyagok, élőállatok, élelmiszerek) közölték a behozatali és kiviteli árindexeket.

\footnotetext{
${ }^{3}$ A külkereskedelmi cserearány azt fejezi ki, hogy hány százalékkal több vagy kevesebb importterméket tud az ország vásárolni egységnyi exporttermékért, mint korábban. A mutatót úgy számítják ki, hogy az exportált termékek árindexét osztják az importált termékek árindexével.
} 
1976-tól a nemzetközi adatok között két új, illetve visszatért árindexes táblázat is megjelent: az „Export árindexek a tőkés világpiacon” (unit value indexek 1972 és 1976 között, a fontosabb feldolgozott ipari termékek, alapanyagok, élelmiszerek körére) és a „Fogyasztói árindexek” (30 országban). A nemzetközi rész 1977-től tovább bővült „A külkereskedelmi árindex országonként” (behozatali, kiviteli árindexek és cserearány-mutatók) táblázattal.

Az 1970-es és 1980-as években felduzzadt adat-előállítás eredményei meghaladták a statisztikai évkönyv keretét, lehetőségeit. Ezért az évkönyvben csak az általános érdeklődésre számot tartó éves adatokat közölték, a részletes szakmai és évközi adatokat szakmai ágazati évkönyvekben adták ki. Megjelentek speciálisan csak az egyes szakmai területek áraival foglalkozó kiadványok is. Így például a „Mezőgazdasági árak, 1960-1983”; „Az ipari termelői árak alakulása, 1971-1981; az „Építöipari árak alakulása, 1976-1980”; a „Kiskereskedelmi áralakulás” (évente); a „Külkereskedelmi áralakulás, 1981”; „A fogyasztói árak változása a lakosság főbb rétegeinél" (évente) címü KSH-kiadványok. Nyilvános módszertani füzetekben tették közzé az árindexek számításának metodikáját is.

\section{A rendszerváltástól az EU-csatlakozásig (1990-től 2004-ig)}

Az 1980-as évek végén gyökeres politikai, gazdasági és társadalmi változások történtek, melyek az áttérést (visszatérést) jelentették a társadalmi tulajdonról a magántulajdonra, a tervgazdálkodásról a piacgazdaságra. Az árrendszer, árpolitika fokozatosan átalakult. Nem szünt meg, de korlátozottabbá vált a hatósági árszabályozás. Nagy lépés volt a piacgazdaság létrehozása felé a forint 1996. évi részleges, majd 2001. évi teljes konvertibilitásának megteremtése.

A gazdasági társaságokról szóló törvény 1988. évi elfogadását követően ugrásszerủen megnőtt a gazdasági szervezetek száma. Az adatszolgáltatási fegyelem romlott. A kisszervezet korábbi módszerek szerinti megfigyelése a nagy számuk miatt lehetetlenné vált. Az adatszolgáltató vállalatok kijelölésénél is a reprezentatív módszerek mind szélesebb körü alkalmazására volt szükség, az átállás azonban zökkenőkkel járt, időt vett igénybe.

Az árak szerepének felértékelődése mutatkozik abban is, hogy az 1995. évi évkönyvtől napjainkig ismét külön fejezetben jelennek meg az árak, egybegyüjtve a korábban ágazati szakmai fejezetekbe sorolt árstatisztikai táblázatokat.

Az évkönyvben publikált árstatisztikai táblázatok száma 1990 után, föként a szükséges módszertani váltás következtében 2004 és 2006 között 16-ra csökkent. A csökkenés fö oka, hogy megszünt a kiskereskedelmi árak, árindexek tábláinak közlése. A 
két építőipari és a beruházási árak táblázatból is csak egy maradt. Technikai okok miatt is csökkent az évkönyvtáblázatok száma, egyes években más adatokkal összevont táblázatba kerül például az agrárolló és a külkereskedelmi cserearány-mutató.

A kiskereskedelmi árak gyüjtése, üzletekben, piacokon való összeírásának koordinálása a hivatalon belül átkerült a fogyasztóiár-statisztikához. Ettől kezdve a kiskereskedelmi volumenindexek képzéséhez szükséges deflátor árindexeket a fogyasztói ár összeírásából származó árindexek átsúlyozásával képezték, és külön nem közölték. Összevonták a korábban külön kezelt termékszintü táblázatokat is, és a fogyasztói árak között közölték.

Az új körülményekhez alkalmazkodva néhány árindexmutató számításának módszertanában átmeneti ideig kényszermegoldásokat kellett alkalmazni.

- A mezögazdasági árstatisztikában 1990 és 2004 között megnőtt az igény a havi árak megfigyelésére. Ezt a feladatot nehezítette, hogy a termelés elaprózódása miatt sokkal több céget kellett megfigyelni. A felvásárlási ár mögött már nem az állami és a szövetkezeti értékesítést értették, hanem a nagy tételben történő első értékesítést, jellemzően nagykereskedőnek vagy feldolgozónak. A piaci ár továbbra is a kis tételben közvetlen értékesítést jelentett a termelötől a lakosság részére. $\mathrm{Az}$ ármegfigyelés ezután is két csatornán történt. A felvásárlási árhoz konkrét mennyiség tartozott, így súlyozott éves árat is tudtak számolni. A piaci árnál a leggyakoribb árat határozták meg, a kijelölt piacon és napon. A két adatból nem számoltak összevont (súlyozott) árat vagy árindexet.

- Az épitooipariár-index számításának változását az kényszeríttette ki, hogy az 1990-es évekre az építőipar struktúrája nagymértékben átalakult. Az 1980-as években megindult szervezeti változások eredményeképpen a kisszervezetek súlya a nagyszervezetek rovására jelentősen megnőtt. Érvényét vesztette több kötelező előírás, így az árképzésre vonatkozó is. A kis- és középvállalkozások, mivel amúgy is szük kapacitással rendelkeztek, már nem mindig készítettek tételes költségvetést és számlát, a statisztikai kérdőívek kitöltése pedig időigényes és bonyolult többletmunkát jelentett számukra. Közben a tételek száma a külkereskedelem és az építőanyag-ipar fejlödésének hatására olyannyira megnövekedett, hogy a tételgyüjtemények már nem tudták követni. Mindezek következtében a jelentések száma erősen csökkent, a tételindexek nagymértékben szóródtak, ami odavezetett, hogy a kérdőíves adatgyüjtést a KSH 1992-ben megszüntette. 1992-töl (egészen 2007ig) a hivatal becsléssel határozta meg az építőipariár-indexet. Az eljárás lényege, hogy az építőiparban felhasznált anyagok termelői árának 
és az építőipari dolgozók keresetének változását súlyozták össze. A két költségnem indexét alágazatonként, a tárgyévet megelőző éves beszámolójelentésben szereplő arányokkal súlyozva határozták meg, az alágazati indexekből a tárgyidőszakot megelőző év építőipari tevékenységének értékével súlyozva számították az építöipar árindexét.

- A külkereskedelmiár-statisztika területén a külkereskedelmi monopólium megszünésének, a külkereskedelmi forgalmat lebonyolító vállalkozások számának ugrásszerü növekedése úgy hatott, hogy a KSH 1991-töl 2002-ig áttért a vámstatisztika által regisztrált termékforgalom adataira támaszkodó egységértékindex számításra. Az így számított indexek a termékcsoporton belüli összetétel-változás hatását is árváltozásként tüntetik fel.

Az ipari árstatisztika területén módszertani finomítások, aktualizálások történtek ebben az időszakban. Így a tevékenységi osztályozás változása (TEÁOR'92 [Gazdasági Tevékenységek Egységes Ágazati Osztályozási Rendszere], TEÁOR'98, TEÁOR'03), a súlyrendszer frissítésének 1995-től éves gyakoriságúvá tétele, 1996tól az ITJ (Ipari Termékek Jegyzéke) felváltása BTO-ra (Belföldi Termékosztályozás), 1998-tól az EU új rendeltetési csoportosításának (MIGs [main insustrial groupings - föbb ipari csoportok) bevezetése.

\section{Az EU-csatlakozástól napjainkig (2004-től 2017-ig)}

Az EU-hoz való csatlakozási szándék 1994. évi kinyilvánítását és a tárgyalások 1998. évi megkezdését követően a magyar statisztikai rendszer EUkövetelményekhez igazítása is kezdetét vette. Deklarált cél volt a statisztikai fejezet tárgyalásánál, hogy Magyarország ne éljen a későbbi adatátadási határidők lehetőségével (ne kérjen „derogációt”). Azaz a magyar statisztikai rendszer minden elöírásnak feleljen meg az EU-csatlakozás idejére. A KSH munkatársai részt vettek az Eurostat (Európai Unió Statisztikai Hivatala) felkészítő értekezletein, amelyet a 11 csatlakozni kívánó (candidate) közép- és kelet-európai országok számára rendeztek. A megfeszített módszertani munka eredményeként a csatlakozás idejére valamennyi kötelező statisztikát az elöírt formában és tartalommal szolgáltatta a KSH az Eurostatnak, megelőzve ezzel több, már korábban az EU tagjává vált (derogációs lehetőséggel élö) országot.

A módszertani egységesítés főként a nemzetközi összehasonlíthatóság biztosításából és a hiányzó statisztikák bevezetésének kikényszerítéséből állt, mindez ugyan- 
akkor azzal járt, hogy módszertani kérdésekben a döntés kikerült a KSH kezéből. Mivel az egységes EU-statisztikák megteremtésénél gyakran a legkevésbé fejlett statisztikájú országok lehetőségeihez igazodtak, esetenként a harmonizáció nem elörelépést jelentett, hanem a korábbi, a hazai körülményeknek megfelelően kifejlesztett statisztikák mellett az EU-elóírásoknak megfelelő statisztikai mutatók előállítását és átadását az Eurostatnak.

Az árstatisztikák területén az EU-előírások egyik oldalról a nemzeti számlák igényeinek megfelelő, azonos elméleti alapokon nyugvó árindexek előállítását szorgalmazták, másik oldalról viszont az ágazati statisztikákról szóló rendeletekben a szakmai statisztikákhoz jobban illeszkedő módszertani elveket (árindexformula, súlyrendszer) érvényesítettek.

Az EU 2002-ben rendeletben (990/2002/EK) írta elő tagországai számára, hogy a nemzeti számlák előállításához „A” (javasolt) és „B” (elfogadható) minősítésű árindex elóállítási módszereket alkalmazzanak, illetve a lehetőségekhez képest kerüljék a "C" (nem elfogadható) módszerek használatát (Official Journal of the European Union [2002]). Az „A” és „B” típusú árindexeket a valós tranzakciós árak megfigyelése alapján számítják ki. „C” típusú indexnek tekinthetők például a különféle közelítő módszerek (mint az átlagos állományi létszám, a felhasznált munkaóra, a mennyiségre vonatkozó mutatók) vagy a nyilvános lista- és ajánlati árak szerint meghatározott viszonyszámok.

\section{1. Új árstatisztikák bevezetése}

Az EU-csatlakozást követően a legnagyobb jelentőségű a korábban Magyarországon meg nem figyelt üzleti célú szolgáltatások termelői árstatisztikájának bevezetése volt. (A lakossági célú szolgáltatások nagy részének ármegfigyelése a fogyasztóiár-statisztika keretében már nagy múltra tekintett vissza.)

A szolgáltatási statisztikákkal foglalkozó Egyesült Nemzetek Szervezete Statisztikai Bizottság Voorburg Csoportjának módszertani ajánlásait és kézikönyvét követve, az Eurostat a (1158/2005/EK számú) rövid távú statisztikákról szóló módosított rendeletben írta elő az üzleti szolgáltatások jelentős részét lefedő árindexek előállításának kötelezettségét (Az Európai Unió Hivatalos Lapja [2005]).

A hazai adatgyüjtési rendszer és módszertan kidolgozása EU-támogatással finanszírozott projekt segítségével történt. Az új, negyedéves, „Az üzleti szolgáltatások kibocsátási árjelentése" című, vállalkozásokat érintő adatgyüjtés 2007-ben indult.

$\mathrm{Az}$ árstatisztikai megfigyelés - aminek eredményeként a KSH jelenleg tizennégy szolgáltatáscsoport szolgáltatásiár-indexét publikálja - nem teljes lefedettséggel, négy nemzetgazdasági ágat (szállítás, raktározás; információ, kommunikáció; szakmai, tudományos müszaki tevékenység; adminisztratív és szolgáltatást támogató tevékeny- 
ség), ezen belül 16 szolgáltatáscsoportot érint, ami 36 szakágazat adatainak aggregálását jelenti. Az érintett szolgáltatáscsoportok árindexeit a KSH két ütemben (2011-töl és 2012-től) kezdte el publikálni kiadványaiban (Hamvainé Holocsy [2016]).

Ezekkel az új árindexekkel a GDP elóállításában (mintegy kétharmad részt kitevő szolgáltatáscsoportok közül) közel 12 százalékot fednek le.

Hiánypótlónak számított a KSH új, EU-elöírásoknak megfelelö lakáspiaci árak, lakásárindexek statisztikájának kialakítása is.

Az ármegfigyelések forrása a Nemzeti Adó- és Vámhivatal illetékhivatali adatbázisa, ahonnan az illetékkiszabásban keletkező információkat a KSH a beérkezés után havonta, anonimizálva veszi át. Az adatátadás minden - magánszemélyek között kötött és a teljes lakás átruházásával járó - adásvételre kiterjed, tartalmazza a lakások eladási ára mellett azok legfontosabb jellemzőit is. 2007-től kezdődően állnak rendelkezésre egységes szerkezetü, összehasonlítható adatsorok, melyek lehetővé teszik a lakáspiac árváltozásának részletes vizsgálatát. A KSH egyik legújabb árindexe először a KSH elektronikus kiadványában, a Statisztikai tükör 2010. júniusi számában jelent meg „Lakáspiaci árak, lakásárindex, 2007-2009 (előzetes adatok)” címen. Közzététele azóta is ebben a formában valósul meg negyedévenként. A kiadványban az összes árváltozást felbontják új és használt lakásokra, ezeken belül a teljes árváltozást összetételhatásra és tiszta árváltozásra. A magyarországi adatok mellett bemutatják az EU-országok árindexeit és az EU-átlagot is.

\subsection{A meglevő árindexek EU-harmonizálása}

Az EU elöírásoknak megfelelően a KSH 1997-től elóállítja a nemzeti fogyasztási árindex mellett a harmonizált fogyasztóiár-indexet, melynek célja, hogy az EUtagországokban biztosítsa az adatok összehasonlíthatóságát a COICOP (Classification of individual consumption according to purpose - az egyéni fogyasztás rendeltetésszerủ osztályozása) nemzetközi nomenklatúra szerint.

Az EU-n belüli vámhatárok 2004. május 1-jei megszünése következtében a korábbi vámstatisztikai adatok helyett az uniós külkereskedelemröl közvetlenül a forgalmazó cégektől kellett az újonnan kiépített Intrastat-rendszeren keresztül a statisztikai adatokat begyüjteni. Az átállással párhuzamosan a külkereskedelmiár-index számítása területén az EU-harmonizációs fejlesztési munkák keretében a KSH 2003-tól áttért a nagyrészt önálló statisztikai adatgyüjtésen alapuló tényleges piaci árak megfigyelésére.

2008-ban a hivatal megkezdte a közvetlen, kérdöíves ármegfigyelésen alapuló épitőipari termelőiár-index számítását. Adatszolgáltatók az építöiparba sorolt kijelölt vállalkozások (mintegy 900). A megfigyelés az építési munkafolyamat felbontásával nyert homogén elemek, az építési tételek egységáraira irányult. Az egyedi reprezentáns-viszonyszámból vállalati indexeket, majd alágazati, ágazati árindexeket, illetve 
építménycsoportok árindexét állítják elő. Az új indexek kielégítik a nemzeti számlák EU által elöírt fejlesztési igényeit.

A mezögazdaságiár-statisztikában az EU-harmonizáció a legnagyobb változást az indexszámításban az ötéves fix bázisra való átállás jelentette. Korábban a mezőgazdaságiár-index számításánál a KSH évente változó súlyozást alkalmazott.

Az új körülményekhez igazodó statisztika már nemcsak a papíralapú évkönyvekben jelent meg, hanem 2005 és 2011 között évkönyvi CD-melléklettel, majd 2012-től internetes melléklettel.

\section{7. Árstatisztikák napjainkban és a fejlesztés iránya}

Napjainkban a KSH-ban szerteágazó árstatisztikai tevékenység folyik, a szakmai munkát több szervezeti egységben, az ágazati szakstatisztikák keretein belül művelik. A magyar árstatisztika megfelel az európai színvonalnak, teljesíti az EUjogszabályok által elöírt követelményeket, a hivatal átadja az Eurostatnak az elöírt adatokat, lépést tart az EU módszertani fejlesztéseivel.

\begin{tabular}{|c|c|c|c|c|c|c|}
\hline \multirow{3}{*}{ Ár, árindex } & \multirow{2}{*}{\begin{tabular}{|c} 
Magyar \\
statisztikai \\
évkönyv, \\
2016
\end{tabular}} & \multicolumn{4}{|c|}{ STADAT (a KSH internetes honlapján) } & \multirow{3}{*}{$\begin{array}{l}\text { Gyorstájékoztató, } \\
\text { Statisztikai tükör }\end{array}$} \\
\hline & & $\begin{array}{l}\text { Hosszú } \\
\text { idősorok }\end{array}$ & $\begin{array}{l}\text { Éves } \\
\text { adatok }\end{array}$ & $\begin{array}{l}\text { Évközi } \\
\text { adatok }\end{array}$ & $\begin{array}{c}\text { Nemzet- } \\
\text { közi } \\
\text { adatok }\end{array}$ & \\
\hline & \multicolumn{5}{|c|}{ árstatisztikai táblázatainak száma (db) } & \\
\hline Fogyasztói árak & 9 & 1 & 5 & 6 & 1 & Gyorstájékoztató (6)* \\
\hline Külkereskedelmi árak & 2 & & 5 & 5 & & Gyorstájékoztató (3)*** \\
\hline Mezőgazdasági árak & 3 & & 6 & 7 & & Gyorstájékoztató (7)* \\
\hline Ipari termelöi árak & 3 & & 3 & 6 & 1 & Gyorstájékoztató (6)* \\
\hline Építőipari árak & 1 & & 3 & 3 & & Gyorstájékoztató $(2)^{* *}$ \\
\hline Beruházási árak & 1 & & 1 & & & \\
\hline Szolgáltatási árak & 1 & & 2 & 2 & & Statisztikai tükör (2) $)^{* * * *}$ \\
\hline Lakáspiaciár-index & & & & 1 & & Statisztikai tükör (1)**** \\
\hline Összesen & 20 & 1 & 25 & 30 & 2 & \\
\hline
\end{tabular}

Megjegyzés. * havi; ** ágazati (más szakmai adatok mellett) havi; *** negyedéves gyakoriságú megjelenés. A Gyorstájékoztatók és a Statisztikai tükrök adattáblázatai a STADAT évközi adatok részében, az elektronikus kiadvánnyal egy idöben jelennek meg. Zárójelben a kiadványhoz kapcsolt STADAT évközi táblázatainak száma szerepel. 
A szerteágazó árstatisztikai tevékenység eredményeit az érdeklődők ma már elsősorban a KSH elektronikus adatközlésein keresztül érhetik el. Továbbra is fennmaradtak a papíralapú adattárak (Magyar statisztikai évkönyv, Magyar statisztikai zsebkönyv), melyek a legfontosabb mutatók éves alakulását közlik. Az éves adatok mellett az évközi (havi, negyedéves) legfrissebb adatokat a hivatal internetes honlapján (www.ksh.hu/arak) megtalálható adattárak (STADAT-táblázatok, tájékoztatási adatbázis) tartalmazzák. A rövid, szöveges elemzéssel kiegészített legfrissebb áradatokat, árindexeket a hivatal elöre kiadott közzétételi időpontokban, a havi Gyorstájékoztatókban hozza nyilvánosságra. A szolgáltatási árak, valamint a lakáspiaciár-index legfrissebb adatait a negyedéves gyakoriságú Statisztikai tükör internetes kiadvány közli.

A KSH internetes honlapján megtalálható STADAT adatbázishoz kapcsolva elérhetők árindextípusonként a részletes módszertani leírások és a metainformációk. Megtalálhatók az árindexszámítások érdekében gyüjtött és átvett adatokat elrendelő OSAP (Országos Statisztikai Adatfelvételi Program) fontosabb információi (a kérdőív nyilvántartási száma, címe, az adatszolgáltatók köre, a beérkezési határidők, az adatgyüjtés jogi alapját elóíró uniós jogszabály száma).

Az Eurostatnak átadott magyarországi adatok - más EU-tagországok adataival együtt - az Eurostat internetes adatközlésein keresztül érhetők el (www.ec.europa.eu/ eurostat).

\subsection{A jelenlegi árstatisztikák főbb jellemzőinek összefoglalása}

A fogyasztóiár-statisztika célja a fogyasztóiár-index és az ebből számított alternatív árindexek előállítása, a fogyasztóiár-színvonal változásának mérése, a fizetőeszköz vásárlóerejében bekövetkezett változás mérése a lakosság körében. A szakstatisztika nemzetközi jogi alapját a harmonizált fogyasztóiár-indexekről szóló 2016/792 EU-rendelet adja (Az Európai Unió Hivatalos Lapja [2016]).

Az árváltozások mérése a termékek és szolgáltatások reprezentánsaiból összeállított fogyasztói kosár alapján történik. A fogyasztói kosarat évente frissítik a lakossági fogyasztás legfrissebb adatainak megfelelően. A „Fogyasztói árösszeírás” címü (1006. számú OSAP-) adatfelvétel keretében meghatározott reprezentánsok árát a KSH összeírói havonta minden megyében feljegyzik, a kijelölt üzletekben, szolgáltatóhelyeken, piacokon (mégpedig több felíróhelyen). Így havonta reprezentánsonként 35-150, összesen mintegy 80 ezer ár gyülik össze az árindexszámításhoz.

A felmerült hazai igényeknek megfelelően, új alternatív, származtatott fogyasztóiár-indexeket is számít a KSH. Az alap- vagy maginflációs mutató célja, hogy a fogyasztóiár-indexet megtisztítsa az egyszeri hatásoktól (például az időjárás, a világpiaciár-mozgás stb.), feltárva az infláció ún. kemény magjának, az alapinflációnak az alakulását. Számítása során a fogyasztóiár-indexből kihagyják a nem feldol- 
gozott élelmiszereket, a háztartási energiát, a jármúüzemanyagokat, a társadalombiztosítás által támogatott gyógyszereket, a hatósági áras szolgáltatásokat.

A VAI (változatlan adótartalmú árindex) számítása során a termékeket és szolgáltatásokat terhelö fontosabb indirekt adók (áfa, jövedéki adó, fogyasztási adó, regisztrációs adó) változásának hatását szüri ki a fogyasztóiár-indexből. A mutató arra a kérdésre ad választ, hogy mekkora lenne az árindex, ha még mindig a bázisidőszakban érvényes adótörvények lennének hatályban.

A nyugdíjasokra vonatkozó fogyasztóiár-index számítása során az ezen társadalmi réteg sajátos fogyasztási szerkezetét tükröző súlyarányokkal készül az árindex.

A külkereskedelmiár-statisztika célja a külkereskedelmi termékforgalom árszínvonal-változásának mérése és deflátor árindex elóállítása a volumenméréshez. Nemzetközi jogi alapját a nemzeti és regionális számlák európai rendszeréről szóló 2223/96/EK tanácsi rendelet „A” mellékletében szereplő 98/725/EK bizottsági határozat és az 549/2013/EU rendelet alkotja (Az Európai Unió Hivatalos Lapja [1996], [2013]). Adatforrás szempontjából az árindexszámítás két pilléren áll: 1. Az árak alakulása szempontjából heterogén árufőcsoportoknál, melyek a külkereskedelem közel 87 százalékát adják, a KSH „Reprezentatív külkereskedelmi árstatisztika” címü (1005. számú OSAP-) kérdőívén szolgáltatják havonta a kijelölt, külkereskedelmi tevékenységet folytató vállalkozások a reprezentáns termékek átlagos havi tranzakciós egységáradatát; 2. A forgalom mintegy 13 százalékát képviselő homogén termékkörökre (élelmiszerek, nyersanyagok, energiahordozók) a külkereskedelmi termékforgalmi statisztika mennyiségi és értékadatából számított egységértékeket használják. A csererány-mutató a kiviteli és a behozatali árindex hányadosa.

A mezögazdaságiár-statisztika két ága 1. a termelöi és 2. a ráfordítási árak és árindexek előállítása, közlése. A termelői árak statisztikájának célja a mezőgazdasági termékek termelői (kibocsátási) árának megfigyelése, a termelői (kibocsátási) árindexek számítása és közzététele. A ráfordítási árak statisztikája a mezőgazdasági termelők által felhasznált termékek, szolgáltatások árának megfigyelésével és az árváltozás számszerüsítésével foglalkozik. Mindkét szakstatisztika jogi alapja a 138/2004/EK rendelet a közösségi mezőgazdasági számlarendszerről (Az Európai Unió Hivatalos Lapja [2004]). A termelői árstatisztika két KSH-adatgyüjtésen alapul: a „Jelentés a felvásárlásról” címủn (1097. számú OSAP), melyben a KSH kérdőívet a felvásárló (nagykereskedő, feldolgozó) vállalkozások töltik ki és küldik be havonta a hivatalnak, valamint a „Piaci felhozatal és árjelentés” címün (1108. számú OSAP), mely keretében a termelői piacokon a KSH összeírói végzik havonta az adatgyüjtést. A ráfordítási árak megfigyelése három negyedévenkénti KSHadatgyüjtésen alapul: „Takarmányok értékesítési ára” (1824. számú OSAP), „Növényvédő-szerek értékesítési ára” (1826. számú OSAP) és „Állatgyógyászati készítmények értékesítési ára" (1827. számú OSAP), valamint más KSHadatgyüjtések (fogyasztói árak, építőipari árak) eredményeinek átvételén, illetve 
más adatgazdáktól való adatátvételen (Agrárgazdasági Kutatóintézettől a műtrágya-értékesítés, a Vetőmag Szövetség a vetőmagtermelési-adatok). A mezőgazdasági termelőiár-index és a mezőgazdasági ráfordítások árindexének hányadosaként képzik az agrárolló mutatóját.

Az ipariár-statisztika célja az ipari termelőiár-index, az export- és a belföldi értékesítésiár-index számítása, a termelői árszínvonal változásának mérése. Jogi alapja a 1158/2005/EK-rendelet a rövid távú statisztikáról (Az Európai Unió Hivatalos Lapja [2005]). Az alapadatokat az „Ipari termékek és szolgáltatások árjelentése” címú (1007. számú OSAP) vállalkozási adatgyűjtés szolgáltatja. A reprezentatív ármegfigyelés havonta csaknem 1400 gazdasági szervezetre és közel 6 ezer termékre terjed ki. Az árindexszámítás súlyszámait az „Éves termékstatisztika” című adatgyüjtésből veszik át.

$\mathrm{Az}$ épitőipariár-statisztika célja az építési piac ármozgásának bemutatása, építőipariár-index számítása. Alapja az Építőipari tevékenység ára címü (OSAP 1831) KSH adatgyüjtés, amely a (mintegy 900) kijelölt építőipari vállalkozásoktól az építési tételek egységárait kérdezi évente négyszer. Az árindexek számításához a súlyszámokat az építőipari statisztikától veszik át.

A KSH beruházásiár-indexeket is elöállít, mely mutató elsődlegesen a beruházások volumenváltozásának számítására szolgál. A beruházásiár-index szekunder típusú mutatónak minősül, tekintettel arra, hogy más adatforrásokból, azaz ,primer árindexekből” (az építőipariár-, az ipariár-, a külkereskedelmiár-, valamint a mezögazdaságiár-statisztikából) vesz át az adatokat, és azokat a beruházások teljesítményértékének anyagi-műszaki összetétele szerint súlyozza össze.

A szolgáltatási kibocsátásiár-statisztika célja nemzetközileg harmonizált kibocsátási-ár megfigyelési rendszer kialakítása meghatározott üzleti célú szolgáltatási ágazatokra, valamint szolgáltatási kibocsátásiár-indexek előállítása. Nemzetközi jogi alapját az EU 1165/1998 számú, a rövid távú statisztikákról szóló rendelete adja ( $A z$ Európai Unió Hivatalos Lapja [1998]). Az adatokat „Az üzleti szolgáltatások kibocsátási árjelentése" címü (2130. számú OSAP) negyedéves kérdőíven gyüjti a KSH. Az adatszolgáltatók száma 2017-ben mintegy 1500 vállalkozás volt.

Az elözőkön kívül rendszeresen számít a KSH deflátor árindexet a kiskereskedelemre (a fogyasztóiár-megfigyelés árainak átsúlyozásával). Az árindexeket folyamatosan felhasználják a nemzeti számlák számításához.

\subsection{További feladatok}

Az árstatisztika fejlesztésénél több cél elérését kell figyelembe venni. Elö kell állítani a gazdasági ágazatok indikátorait, információkat kell biztosítani a gazdasági élet szereplőinek és az államigazgatásnak döntéseik előkészítéséhez, valamint a dön- 
tések hatásainak monitorozásához. Szélesíteni kell a nemzeti számlák számításához szükséges deflátor árindexek előállítását. Folytatni kell az üzleti szolgáltatások még árindexekkel le nem fedett területeinek bevonását az ármegfigyelésbe.

A szolgáltatási szektor teljesítménye a fejlett gazdaságokban meghaladja a nemzetgazdaság egészére számított bruttó hozzáadott érték kétharmadát. Ugyanakkor az erre a területre kimunkált statisztikai mutatók köre messze elmarad a mezőgazdaság, az ipar és az építőipar jellemzésére rendelkezésre álló indikátorokétól. A felhasználók részéről jelentkező adatigényt az EU a FRIBS (framework of integrated business statistics - gazdaságstatisztika integrálására vonatkozó keretjogszabály) bevezetésével kívánja kiszolgálni. Ennek része a rövid távú statisztikákról szóló csomag, mely a szolgáltatási tevékenységek hiánypótló mutatóit, köztük újabb szolgáltatási kibocsátásiár-indexeket, valamint egy új makrogazdasági mutatót, az ISP (index of services production - szolgáltatási ágazatokra vonatkozó termelésivolumen-index) is tartalmazza.

A FRIBS-tervezetben bevezetendő mutatók közül az ipari és építőipari termelésivolumen-indexhez, illetve a deflált kiskereskedelmi árbevételhez hasonló ISP iránt mutatkozik a legnagyobb igény. A nemzetközi szakirodalom szerint javasolt számítása ideális esetben az értékindex (árbevételindex) és a szolgáltatási kibocsátásiár-indexek mint deflátorok felhasználásával történik.

Az új területek adatgyüjtésbe való bevonásával kapcsolatos hazai előkészítő módszertani munkákat a KSH - a rendelkezésre álló szükös erőforrásokat is figyelembe véve - időben elosztva, fokozatosan tervezi megvalósítani (Hamvainé Holocsy [2016]).

\section{Irodalom}

Az Európai Unió Hivatalos Lapja [1996]: A Tanács 2223/96/EK rendelete (1996. június 25.) a Közösségben a nemzeti és regionális számlák európai rendszeréről. 39. évf. L 310. 1996. 11. 30. 31996R2223. 10/2. köt. 1-471. old. https://eur-lex.europa.eu/legal-content/HU/TXT/PDF/ ?uri=CELEX:31996R2223\&qid=1527842693673\&from $=$ HU

Az EuróPAi Unió Hivatalos Lapja [1998]: A Tanács 1165/98/EK rendelete (1998. május 19.) a rövid távú statisztikákról. 41. évf. L162. 1998. 6. 5. 31998R1165. 13/20. köt. 2091-305. old. https://eur-lex.europa.eu/legalcontent/HU/TXT/PDF/?uri=CELEX:31998R1165\&qid=1528896452114\&from=EN

Az Európai Unió Hivatalos Lapja [2004]: Az Európai Parlament és a Tanács 138/2004/EK rendelete (2003. december 5.) a közösségi mezőgazdasági számlarendszerről. 47. évf. HL L 33. 2004. 2. 5. 32004R0138. 03/42. köt. 290-376. old. https://eur-lex.europa.eu/legalcontent/HU/TXT/PDF/?uri=CELEX:32004R0138\&qid=1527843608964\&from $=\mathrm{HU}$

Az EuRóPAi Unió Hivatalos Lapja [2005]: Az Európai Parlament és a Tanács 1158/2005/EK rendelete (2005. július 6.) a rövid távú statisztikákról szóló 1165/98/EK tanácsi rendelet módosításá- 
ról. 48. évf. L 191. 2005. 7. 6. 1-15. old. https://eur-lex.europa.eu/legal-content/ HU/TXT/PDF/?uri=CELEX:32005R1158\&from=HU

Az Európai Unió Hivatalos Lapja [2013]: Az Európai Parlament és a Tanács 549/2013/EU rendelete (2013. május 21.) az Európai Unió-beli nemzeti és regionális számlák európai rendszeréröl. 56. évf. L 174. 2013. 6. 26. 1-727. old. https://eur-lex.europa.eu/legalcontent/HU/TXT/PDF/?uri=CELEX:32013R0549\&qid=1527843231656\&from=HU

Az EuRópai Unió Hivatalos Lapja [2016]: Az Európai Parlament és a Tanács (EU) 2016/792 rendelete (2016. május 11.) a harmonizált fogyasztói árindexekről és a lakásárindexről, valamint a 2494/95/EK tanácsi rendelet hatályon kívül helyezéséről. 59. évf. L 135. 2016. 5.24 11-38. old. https://eur-lex.europa.eu/legal-content/HU/TXT/PDF/?uri=CELEX:32016R0792\&qid=152 $7842249551 \&$ from $=\mathrm{HU}$

Balogh Gy. - KapÁs J. [1953]: Árindexszámítás a belkereskedelemben. Statisztikai Szemle. 31. évf. 3. sz. 244-250. old.

FARKAS J. [1923]: A magyar kereskedelmi statisztikai értékmegállapító bizottság szervezete és müködése. Statisztikai Szemle. 1. évf. 1-2. sz. 36-37. old.

HAJDU Gy.-NÉ [1994]: Árfolyamrendszer és árfolyam-politika Magyarországon (1946-1993). MNB Mühelytanulmányok 7. Magyar Nemzeti Bank. Budapest.

HamvainÉ Holocsy I. [2010]: A szolgáltatási kibocsátási árindex számítása és főbb jellemzői. Statisztikai Szemle. 88. évf. 5. sz. 532-545. old.

HAMVAINÉ Holocsy I. [2016]: A szolgáltatási kibocsátásiár-indexek deflátor szerepkörben módszertani fejlesztés Európában és Magyarországon. Statisztikai Szemle. 94. évf. 1. sz. 22-51. old. http://dx.doi.org/10.20311/stat2016.01.hu0022

KSH (KöZPONTI StatiSZTIKAi HivATAL) [1872-2016]: Magyar statisztikai évkönyv. Budapest.

KSH [1957]: Áralakulás Magyarországon 1938-ban és 1949-1955-ben. Statisztikai Időszaki Közlemények. 1. sz. Budapest.

KSH [2001]: Külkereskedelmi Indexsorok - External Trade Indices 1950-1999. Budapest.

LAKATos M. [2009]: Beszélgetés dr. Marton Ádámmal. Statisztikai Szemle. 87. évf. 12. sz. 12151221. old.

LENCSÉS Á. [2017]: A Magyar statisztikai évkönyv szerkezetének változásai 1872 és 2016 között. Statisztikai Szemle. 95. évf. 11-12. sz. 1144-1158. old. http://dx.doi.org/10.20311/stat2017.1112.hu1144

Magyar KirÁlyi Statisztikai Hivatal [1911]: A Magyar Királyi Központi Statisztikai Hivatal munkássága 1871-1911 - a hivatal fennállásának negyvenedik évfordulója alkalmából. Statisztikai Közlemények. 36. köt. Budapest.

Magyar KirÁlyi Statisztikai Hivatal [1913]: Árstatisztika. Statisztikai Közlemények. 44. köt. Budapest.

MARTON Á. [1961]: A reprezentatív módszer alkalmazásának néhány kérdése a külkereskedelmi árindexszámításban. Statisztikai Szemle. 39. évf. 2. sz. 147-159. old.

Marton Á. [1968]: Az új kiskereskedelmi árstatisztikai megfigyelések. Statisztikai Szemle. 46. évf. 10. sz. 985-997. old.

MARTON Á. [1979]: A külkereskedelmi árak változásai az 1920-as évek óta. Statisztikai Szemle. 57. évf. 8-9. sz. 806-816. old.

MARTON Á. [2004a]: Az árindexek minőségét befolyásoló tényezőkről. Statisztikai Szemle. 82. évf. 9. sz. 859-865. old. 
Marton Á. [2004b]: Az árindexekről. A mai gyakorlat, a fejlesztés irányai. Gazdaság és Statisztika. 16. (55.) évf. 2. sz. 39-60. old.

MARTON Á. [2012]: Infláció, fogyasztói árak Magyarországon a második világháború után I. (1945-1968). Statisztikai Szemle. 90. évf. 5. sz. 373-393. old.

Marton Á. [2015]: Gondolatok az inflációról több évtized távlatában. Statisztikai Szemle. 93. évf. 5. sz. 442-459. old.

Official Journal of the European Union [2002]: Commission Decision of 17 December 2002 Further Clarifying Annex A to Council Regulation (EC) No 2223/96 as Concerns the Principles for Measuring Prices and Volumes in National Accounts. 20.12.2002. L 347. pp. 42-59. https://eur-lex.europa.eu/legal-content/EN/TXT/PDF/?uri=CELEX:32002D0990\&qid=152889 $3814681 \&$ from $=\mathrm{EN}$

PÁLos I. - ZAFIR M. [1959]: A kiskereskedelmi áruforgalmi statisztika fejlesztésének kérdései. Statisztikai Szemle. 37. évf. 11. sz. 1115-1127. old.

SimON S. [1967]: Az árstatisztika új feladatai és módszerei. Statisztikai Szemle. 45. évf. 4. sz. 288303. old.

STATISZTiKai SzEMLE [1925]: A hivatalos létfenntartási indexszámok. 3. évf. 5-6. sz. 191-197. old.

StATiszTiKai SzEMLE [1927]: A létfenntartási költségek indexszámai az 1914-1926 években. 5. évf. 6. sz. 588-591. old.

STATISZTIKAI SzEMLE [1958]: A KSH Kollégiumának határozata az árindex súlyozásával kapcsolatban. 36. évf. 7. sz. 672. old.

SüVEGES É. [2004]: Az üzleti szolgáltatások árstatisztikájának helyzete az OECD országokban. Gazdaság és Statisztika. 16. (55.) évf. 6. sz. 55-66. old.

SzŐNYI Gy. [1924]: A magyar nagykereskedelmi árak indexszámai. Statisztikai Szemle. 2. évf. 7-8. sz. 315-321. old.

SzŐNYI Gy. [1939]: A magyar nagykereskedelmi árak indexszámainak új sorozata. Statisztikai Szemle. 17. évf. 3. sz. 275-307. old.

TŰÜ L.-NÉ [1958]: Az 1957/56. évi ipari termelöi és anyagárindex-számítások. Statisztikai Szemle. 36. évf. 8-9. sz. 829-839. old.

Vukovich Gy. [1992]: Emlékezés és előretekintés. Statisztikai Szemle. 70. évf. 8-9. sz. 654-663. old.

ZAFIR M. [1968]: A kiskereskedelmi árstatisztika alapjai. Statisztikai Szemle. 46. évf. 2. sz. 180192. old.

ZAFIR M. [1991]: A régi létfenntartási indexszámok mai szemmel. Statisztikai Szemle. 69. évf. 4-5. sz. 366-367. old.

ZAFIR M. [1992]: Fordulópontok a fogyasztói árak statisztikájának hazai történetében. Statisztikai Szemle. 70. évf. 8. sz. 725-740. old. 


\section{Summary}

Official price statistics has seen a significant improvement in Hungary during the last 150 years. Initially the HCSO (Hungarian Central Statistical Office) collected, processed and published the prices of (mainly) agricultural and mining products recorded by larger markets or the stock market. Later official producer price statistics was built on data collected from agricultural, industrial, construction and business services enterprises through HCSO questionnaires, and official consumer price statistics was based on prices quoted by the marketers of markets, shops and services. After EU accession, a decisive task was to meet both EU standards and domestic needs. Nowadays elaboration of the currently missing price indices of certain business services and the unified index of services production has been in the focus of development. 